\title{
同胞間における歯冠幅（煩舌的）。口蓋 の大きさの相関
}

I 同胞間に扣ける口腔形質二、三の相関

九州歯科大学衛生学教室（指導 荷宮文夫教授)

大 沢幸 男

\section{まえがき}

近来、人類遺伝学は急速の進歩をきたし、正常形質 の遗伝、悪質形質の遺伝について多くの研究が行わ れ、諸種の悪質遺伝病か解明されつつある。しかし、 曾科領域に和ける諸形質、乙とに悪質遗伝病の遺伝に ついては、いまだみるい゙き研究はない。

口腔形質の遺伝についての研究は、岡田1、和田2)、 岩垣3、同本4)、田所5)などの発表がある。教室では、 荷宮 6 - 10)秘双生児、親子の頡、顔、口腔諸形質、側切 歯の畸型崡とカラベリー結節など遺伝学的研究を行な

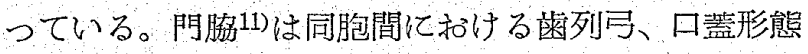
の類似性、宮島 ${ }^{12)}$ は齒牙の捻転度、阿南 ${ }^{13}$ は歯冠幅

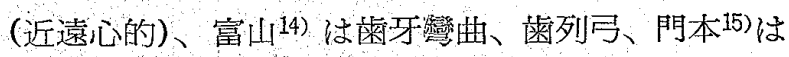
口吻度、津島 ${ }^{16)}$ は橉牙交換並びに䁬歯について遺伝学 的研究を行なっている。

茵冠の近遠心的菌冠幅について、阿南 ${ }^{13}$ は双生览、 親子、同胞に扣ける相関性登表し、性組合せ内に抏 ける相関は、双生児がもつともきく、なかでも一卵 性双生紧がっっも大、同性二卵性双生児，異性二卵 性双生巟がつとる小さい。奴生巟についで、同胞、 すなわち、兄弟、姉妹、兄妹（弟姉）の各組合せ群の 近遠心的歯冠䒇の相関関係があると発表した。

口腔の正常な形質の遺伝を研究することは、雪学上 重要な意義を有する。口腔諸形質について上のように かなり詳細に研究されているが、まだ、口腔諸形質 は、充分に明らか忆されていな。

私はてのような重要な意義を有するてとより、な扔 明らかにされていない口腔諸形質について研究を行な

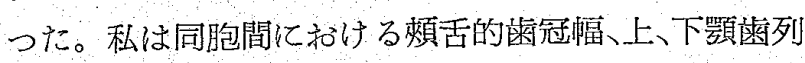

弓の周長、日蓋弓隆長、口蓋幅などについて、同胞間の 性組合せ内の相関々係を比較し、遗伝性を研究した。 研究成績の概要を報告せんとするものである。

\section{対 象}

研究に用いた対象は、北九州居住の同胞16〜30才、

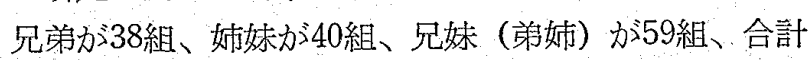
137組、274名である。同胞の性組合せの各組合せの年 令差が少なく、知菡を除いた永久画の生娄しているも ので、測計のできない漓承を有するものは除いた。 れらの対象の口腔印象石䇾模型を製作し、石骨模型上 で測計を行なった（第1表）。

\section{測計した項目}

\section{1. 歯冠幅 (煩舌的)}

頓舌的歯冠腷の測計法は藤田 17 ) の蒾牙基準的測計法 そよった。測計した䨑は、上、下顎左側の中切歯、側

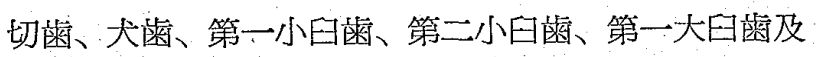
び第二大曰齒の14歯である。

\section{2. 踩列弓周長}

歯列弓周長は疄列弓の大きさ示すもので、歯冠の 近遠心幅の大きされよって左右される。雪列弓周長 は、上、下顎の左右第一大臼崡の近心煩側咬頭頂間、 各歯の唇面及び煩面にヒユーズを圧接して、これ直 線にしてその長さを測阡した。ての測計法は荷宮18)に ならった。

\section{3. 口蓋弓隆の長さ}

口蓋弓隆は口馌の形態の発育状態をみるために口篮 の形態を左右的に観測し、観測は犬歯部、第一小四菡 部、第二小曰歯部、第一大曰画部を測訫した。，口篮弓 
第 1 表

性組合せ別年命表

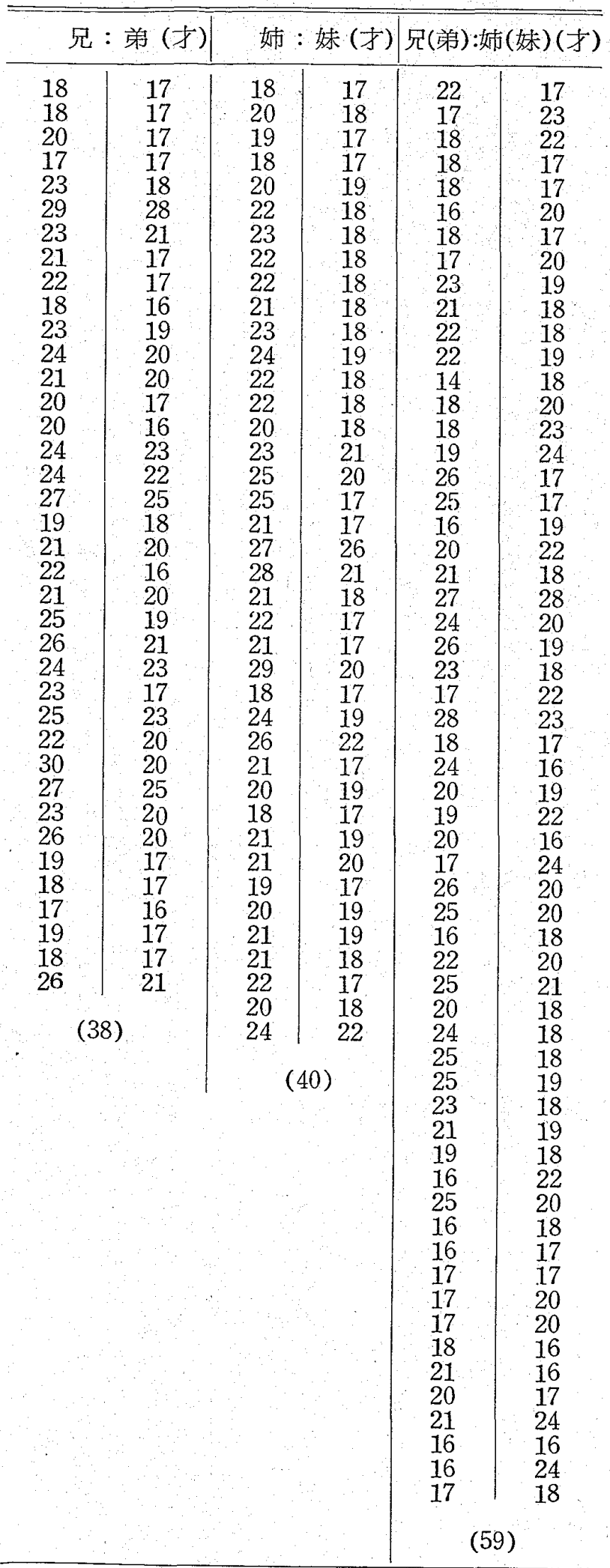

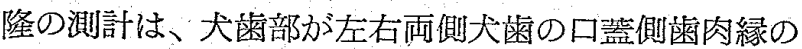
中央を雨端とし口莣面にヒユーズを圧接し、これを直 線とし、との長さを犬歯部口蓋弓隆長とした。同じ方
法によって、第一小曰霜部、第二小曰歯部及び第一大 曰歯部を測計した。

\section{4. 口蓋正中縫合線の長さ}

前方は左右両側中切歯の歯間乳頭部、後方は第一大 臼崡部口望亏隆長の線と口篕正中縫合線とまじわる点 を、測計点とし、正中縫合線にそうてヒユーズを圧接 し、てれを直線にしてその長さを測計した。

\section{5. 口 蓋 幅}

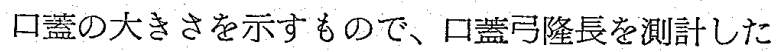
ときの左右両側端間の直線距離である。口蓋幅は大歯 部、第一小曰曾部、第二小曰部、第一大曰歯部を測計 した。

\section{観測値の取扱い}

餡測值の取扱いは、つぎの如くである。

$\mathrm{X}:$ 観測值

$\bar{X}: \mathrm{X}$ の平均值、 $\bar{X}=\frac{\Sigma \mathrm{X}}{\mathrm{N}} 、 \mathrm{~N}:$ 例数

$\mathrm{S} 2 \mathrm{X}: \mathrm{X}$ の分散、 $\mathrm{S}^{2} \mathrm{x}=\frac{\Sigma(\mathrm{X}-\bar{X})^{2}}{\mathrm{~N}-1}$

$r: \mathrm{X} 、 \mathrm{Y}$ の相関係数

$$
\gamma=\frac{\Sigma(\mathrm{xy})}{\sqrt{\Sigma \mathrm{x}^{2}+\Sigma \mathrm{y}^{2}}} \cdot\left\{\begin{array}{l}
\mathrm{x}=\mathrm{X}-\overline{\bar{X}} \\
\mathrm{y}=\mathrm{Y}-\overline{\mathrm{Y}}
\end{array}\right.
$$

$\mathrm{S}_{\gamma}:$ のの標準倔差、 $\mathrm{S}_{\gamma}=\frac{1-\gamma^{2}}{\sqrt{\mathrm{N}-1}}$

二つの平均值の差の判定

級 別

$\mathrm{d}: 2$ つの平均值の差、 $\mathrm{d}=\bar{X}-\overline{\mathrm{Y}}$

$\omega^{2}: \mathrm{X} 、 \mathrm{Y}$ の共同分散、

$$
\begin{aligned}
\omega^{2} & =\frac{\left(\mathrm{N}_{1}-1\right) \mathrm{S}_{2} \mathrm{x}+\left(\mathrm{N}_{2}-1\right) \mathrm{S}_{2} \mathrm{y}}{\mathrm{N}_{1}+\mathrm{N}_{2}-2} \\
\text { to } & =\frac{\mathrm{d}}{\omega} \sqrt{\frac{\mathrm{N}_{1} \times \mathrm{N}_{2}}{\mathrm{~N}_{1}+\mathrm{N}_{2}}}
\end{aligned}
$$

toの值が $\mathrm{t}$ 一表の危険度 $5 \%$ に扣ける、 $\mathrm{n}=\mathrm{N}_{1}+$ $\mathrm{N}_{2}-2$ 亿当る $\mathrm{t}$ 一值より大きいとき、 $\mathrm{d}$ は危除度 5 \%以下に扔いて有意義性がある。

$\mathrm{d}: 2$ つの $の$ 差、 $\mathrm{d}=\gamma_{1}-\gamma_{2}$

$\mathrm{Sd}: \mathrm{d}$ の標準偏差、 $\mathrm{Sd}=\sqrt{\mathrm{S}^{2} \gamma 1+\mathrm{S}^{2} \gamma 2}$

$\mathrm{d} / \mathrm{Sd}$ の值が 2 以上のとき、危険度 $5 \%$ 以下に执 いて、差は有意義性がある。

\section{全般的}

$\mathrm{Mr}$ : 平均比、 $\mathrm{Mr}=\frac{\Sigma(\mathrm{to})}{\mathrm{K}} 、 \mathrm{~K}:$ 比較した級数

$$
\mathrm{Mr}=\frac{\Sigma(\mathrm{d} / \mathrm{Sd})}{\mathrm{K}}
$$

$\mathrm{S}_{\mathrm{Mr}}: \mathrm{Mr}$ の標準偏差、 $\mathrm{S}_{\mathrm{Mr}}=\frac{1}{\sqrt{\mathrm{K}-1}}$ 
$\mathrm{Mr}$ は 0 を中心として、 $\mathrm{SMr}=1 /(\mathrm{K}-1)^{1 / 2}$ を標準 偏差として正規分布するものとみなせば、 $\mathrm{Mr} / \mathrm{S}_{\mathrm{Mr}}$ の 值か 2 上上のとき、危険度 $5 \%$ 以下に打いて有意義性 の差かある。

第 2 表

\begin{tabular}{|c|c|c|c|c|c|c|c|c|c|c|}
\hline \multirow{2}{*}{ \pm} & \multirow{2}{*}{ 顎 左 側 電 } & \multicolumn{3}{|c|}{ 男 } & \multicolumn{3}{|c|}{ 女 } & \multicolumn{3}{|c|}{ 男一女 } \\
\hline & & $\mathrm{N}_{1}$ & $\bar{X}$ & $S^{2} x$ & $\mathrm{~N}_{2}$ & $\bar{Y}$ & $\mathrm{~S}^{2} \mathrm{Y}$ & d & $\omega^{2}$ & to \\
\hline 中 & 切 歯 & 57 & 7.63 & 0.5603 & 57 & 7.42 & 0.4967 & 0.21 & 0.5285 & 1.536 \\
\hline 䫀 & 切 畨 & 56 & 6.61 & 0.3129 & 56 & 6.50 & 0.5455 & 0.11 & 0.4292 & 0.897 \\
\hline 犬 & - 崡 & 57 & 8.30 & 0.3993 & 57 & 8.05 & 0.5153 & 0.25 & 0.4573 & 1.963 \\
\hline & 一 小 $⿴$ 菌 & 56 & 9.70 & 0.4453 & 56 & 9.30 & 0.6985 & 0.40 & 0.5719 & 2.798 \\
\hline & 二小曰 柬 & 56 & 9.72 & 0.6211 & 56 & 9.37 & 0.6325 & 0.35 & 0.6268 & 2.348 \\
\hline 第 & 一大日四 & 57 & 11.82 & 0.5027 & 57 & 11.39 & 0.3890 & 0.49 & 0.4459 & 3.006 \\
\hline 第 & 二大日 & 46 & 11.65 & 0.6170 & 46 & 11.24 & 0.7203 & 0.41 & 0.6687 & 2.400 \\
\hline
\end{tabular}

\section{成 績}

\section{I 男と女の煩舌的歯冠幅の比較}

\section{1. 上 顎}

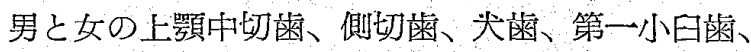
第二小曰霜、第一大曰雪及び第二大曰歯の煩舌的崡冠 幅を比べると第 2 表のと勀りである。

to, $\mathrm{Mr} / \mathrm{S}_{\mathrm{Mr}}$ の值の太字は有意義性を示す。以下同

上顎䨑牙の頉舌的歯冠湢は、側切歯がもつとも小さ く、男が平均 $6.6 \mathrm{~mm}$ 、女が平均 $6.5 \mathrm{~mm}$ 、ついで中切 䨑、犬崡、第一小曰歯、第二小曰歯、第二大曰雾もつ そも大きいのは第一大曰齒で、男务泙均 $11.8 \mathrm{~mm}$ 、女 が平均 $11.4 \mathrm{~mm}$ である。

男女間の差に有意義性のあるのは、第一小四芼、第 二小曰崡、第一大曰歯及び第二大曰歯の 4 電で、いず
れも男が大である。7崡全般的に男女間の差は、 $\mathrm{Mr} / \mathrm{S}_{\mathrm{Mr}}$ が 5.547 で有意義性の差があり、男が女子り も大である。

\section{2. 下 顎}

男と女の下顎左側 7 蒾の平均煩舌的菌冠幅及び男女 間の差を比べると、第 3 表のと扣りである。
第 3 表

下顎 左 側 㙖

下 顎 左 側 崡

中 切雪

側 切崡

犬 歯

第一小曰画

第二小画

第一大歯

第二大曰歯

$\mathrm{K}=7$

男と女の下顎左側歯の煩舌的平均蒾冠幅の比較

男 女 女

\begin{tabular}{|l|l}
\hline & 男 \\
\hline $\mathrm{N}_{1}$ & $\mathrm{X}$
\end{tabular}

56
56
56
55
55

下顎左側䨑の賽舌的歯冠幅は、中切歯がもっとも小 さくて、男が平均 $6.5 \mathrm{~mm}$ 、女は平均 $6.4 \mathrm{~mm}$ 、つい で側切崡、大歯、第一小四歯、第二小曰雪、第一大日
歯、第二大臼雪の順に大きくるっている。

男女間の崡冠幅の差に有意戔性のあるのは、犬崡、 第一大曰崡及び第二大曰雪で、第一大曰雪は女が大き

$(\mathrm{mm})$

\begin{tabular}{l|c|c|c|c|c|c|c|}
\hline $\mathrm{X}$ & $\mathrm{S}^{2} \mathrm{X}$ & $\mathrm{N} 2$ & $\overline{\mathrm{Y}}$ & $\mathrm{S}^{2} \mathrm{Y}$ & $\mathrm{d}$ & $\omega^{2}$ & to \\
\hline 6.52 & 0.5886 & 56 & 6.38 & 0.5359 & 0.14 & 0.5588 & 0.989 \\
6.84 & 0.5011 & 56 & 6.63 & 0.6060 & 0.21 & 0.5536 & 1.504 \\
8.05 & 0.5611 & 56 & 7.77 & 0.5097 & 0.28 & 0.5354 & 2.033 \\
8.47 & 0.4362 & 55 & 8.33 & 0.3335 & 0.14 & 0.3848 & 1.185 \\
8.80 & 0.2371 & 55 & 8.71 & 0.3959 & 0.09 & 0.3165 & 0.814 \\
1.54 & 0.3760 & 53 & 11.90 & 0.6629 & -0.36 & 0.5195 & $-\mathbf{2 . 5 7 5}$ \\
1.98 & 0.4788 & 45 & 11.67 & 0.5208 & 0.31 & 0.4942 & $\mathbf{2 . 1 0 4}$ \\
\hline
\end{tabular}

$\mathrm{Mr} / \mathrm{S}_{\mathrm{Mr}}=2.130$ 
く、他の 2 歯は男が大である。全般的に男女間の差 は、 $\mathrm{Mr} / \mathrm{S}_{\mathrm{Mr}}$ が2.130で有意義性があり、男が大であ る。

\section{3. 上㖽と下顎の比較}

男と女の各々の上顎と下顎の左側同名歯間の頓舌的 雬冠幅の差は、第 $4 、 5$ 表のと打りである。

第 4 表 上顎左側電並びに下顎左側歯の頓舌的歯冠幅の差 (男)

$(\mathrm{mm})$

\begin{tabular}{|c|c|c|c|c|c|c|c|c|c|c|c|}
\hline \multirow{2}{*}{ 左 } & \multirow{2}{*}{ 側 } & \multirow{2}{*}{ 篓 } & \multicolumn{2}{|c|}{ 上 } & 㖽 & \multicolumn{2}{|c|}{ 下 } & 䂓 & \multicolumn{3}{|c|}{ 上 顎一下 顎 } \\
\hline & & & $N_{1}$ & $\overline{\mathrm{X}}$ & $S^{2} x$ & $\mathrm{~N}_{2}$ & $\bar{Y}$ & $\mathrm{~S}^{2} \mathrm{Y}$ & d & $\omega^{2}$ & to \\
\hline 中 & 切 & 䐉 & 57 & 7.63 & 0.5603 & 56 & 6.52 & 0.5886 & 1.11 & 0.5709 & 11.027 \\
\hline 側 & 切 & 崡 & 56 & 6.61 & 0.3129 & 56 & 6.84 & 0.5011 & -0.23 & 0.4070 & -2.692 \\
\hline 犬 & & 雪 & 57 & 8.30 & 0.3993 & 56 & 8.05 & 0.5611 & 0.25 & 0.4795 & 2.736 \\
\hline 第 - & 小曰 & & 56 & 9.70 & 0.4453 & 55 & 8.47 & 0.4362 & 1.23 & 0.4408 & 13.661 \\
\hline 第 & 小曰 & & 56 & 9.72 & 0.6211 & 55 & 8.80 & 0.2371 & 0.92 & 0.4309 & 10.441 \\
\hline & 大曰 & & 57 & 11.82 & 0.5027 & 53 & 11.54 & 0.3760 & 0.28 & 0.4417 & 3.155 \\
\hline 第 & 大日 & 噛 & 46 & 11.65 & 0.6170 & 45 & 10.98 & 0.4788 & 0.67 & 0.5487 & 6. 148 \\
\hline & $=7$ & & & 4 & & & & & & & \\
\hline
\end{tabular}

第 5 表

上顎左側啮並びに下顎左側歯の煩活的歯冠幅の差（女）

$(\mathrm{mm})$

\begin{tabular}{|c|c|c|c|c|c|c|c|c|c|c|c|}
\hline \multirow{2}{*}{ 左 } & \multirow{2}{*}{\multicolumn{2}{|c|}{ 側 賕 }} & \multicolumn{2}{|c|}{ 上 } & 㕷 & \multicolumn{2}{|c|}{ 下 } & 真 & \multicolumn{3}{|c|}{ 上 颚頁一下 顎 } \\
\hline & & & $\mathrm{N}_{1}$ & $\bar{X}$ & $S^{2} x$ & $\mathrm{~N}_{2}$ & $\bar{Y}$ & $S^{2} \mathrm{Y}$ & d. & $\omega^{2}$ & to \\
\hline 中 & 切 & & 57 & 7.42 & 0.4967 & 56 & 6.38 & 0.5359 & 1.04 & 0.5161 & 10.906 \\
\hline 側 & 切 & & 56 & 6.50 & 0.5455 & 56 & 6.63 & 0.6060 & -0.13 & 0.5758 & -1.281 \\
\hline 犬 & & 歯 & 57 & 8.05 & 0.5153 & 56 & 7.77 & 0.5097 & 0.27 & 0.5125 & 2.831 \\
\hline & 小曰 & & 56 & 9.39 & 0.6985 & 55 & 8.33 & 0.3335 & 0.97 & 0.5177 & 9.315 \\
\hline 第 & 小曰 & & 56 & 9.37 & 0.6325 & 55 & 8.71 & 0.3959 & 0.66 & 0.5153 & 6.866 \\
\hline 第 & 大日 & & 57 & 11.39 & 0.3890 & 53 & 11.90 & 0.6629 & -0.51 & 0.5209 & -5.924 \\
\hline 第 & 大日 & & 46 & 11.24 & 0.7203 & 45 & 10.67 & 0.5208 & 0.57 & 0.6247 & 4.899 \\
\hline
\end{tabular}

$\mathrm{K}=7$

$\Sigma($ to $)=27.612 \quad \mathrm{Mr}=3.945 \quad \mathrm{~S}_{\mathrm{Mr}}=0.408 \quad \mathrm{Mr} / \mathrm{S}_{\mathrm{Mr}}=\mathbf{9 . 6 6 9}$

男、女とも上下顎同名歯間では、いずれも有意義性 の差があり、男女とも側切歯は下顎が大きく、他の 6 圈はいずれも下顎が大きく、他の 6 歯はいずれも上顎 が大である。全般的には、 $\mathrm{Mr} / \mathrm{S}_{\mathrm{Mr}}$ が男は15.574、女 は 9.669 で有意義性の差があり、上顎が下顎よりも大 である。

\section{II 歯冠幅（顂舌的）の同胞間における相関}

\section{A. 上顎歯}

同胞の性組合せ別、すなわち、男男（完弟）、女女 (姉妹)、男女（兄妹宗たは姉弟）の各組合せ内に抒 ける上顎左側 7 亚の煩舌的崡冠幅、それぞれ性組合せ 別の相関表と相関係数は、第 6 ～27 表のと打 らであ る。
第 6 表 兄弟間に和ける 1 の頓舌的 歯冠軠の相関 $(\mathrm{mm})$

\begin{tabular}{r|r|r|r|r|r}
\hline \hline $\mathrm{X}$ & 6 & 7 & 8 & 9 & 計 \\
\hline 6 & & 1 & 1 & & 2 \\
7 & 1 & 3 & 4 & 1 & 9 \\
8 & 1 & 7 & 5 & 2 & 15 \\
9 & & $\ddots$ & 2 & & 2 \\
10 & & 1 & 1 & & 2 \\
\hline 計 & 2 & 12 & 13 & 3 & 30 \\
\hline
\end{tabular}

$\mathrm{r}_{1} \pm \mathrm{Sr}_{1}=0.044 \pm 0.185$ 
第 7 表 姉妹間に扑る 1 の煩舌的 歯冠幅の暞関 (mm)

\begin{tabular}{|c|c|c|c|c|}
\hline $\mathrm{Y} X$ & 6 & 7 & 8 & 棓 \\
\hline 5 & & 1 & & 1 \\
\hline 6 & & 2 & 1 & 3 \\
\hline 7 & 1 & 10 & 8 & 19 \\
\hline 8 & & 3 & 11 & 14 \\
\hline 9 & & 1 & & 1 \\
\hline 10 & & & 1 & 1 \\
\hline 計 & 1 & 17 & 21 & 39 \\
\hline
\end{tabular}

$\mathrm{r}_{2} \pm \mathrm{Sr}_{2}=0.314 \pm 0.146$

第 8 表 兄林（弟姉）間に抽引る|1 の 賽舌的歯冠幅の相関 $(\mathrm{mm})$

\begin{tabular}{|r|r|r|r|r|r}
\hline $\mathrm{X}$ & 6 & 7 & 8 & 9 & 計 \\
\hline $\begin{array}{r}\mathrm{Y} \\
6\end{array}$ & 2 & 3 & & & 5 \\
7 & 1 & 10 & 14 & & 25 \\
8 & & 7 & 12 & 6 & 25 \\
9 & & 1 & 1 & & 2 \\
\hline 計 & 3 & 21 & 27 & 6 & 57 \\
\hline
\end{tabular}

$\mathrm{r}_{3} \pm \mathrm{Sr}_{3}=0.597 \pm 0.086$

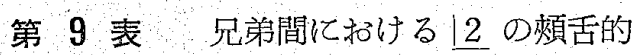
歯冠幅の相関 $(\mathrm{mm})$

\begin{tabular}{r|r|r|r|r|r|r}
\hline $\mathrm{X}$ & 5 & 6 & 7 & 8 & 9 & 計 \\
\hline 6 & 1 & 6 & 4 & 1 & & 12 \\
7 & & 2 & 10 & 2 & 1 & 15 \\
8 & & 1 & 2 & & & 3 \\
\hline 計 & 1 & 9 & 16 & 3 & 1 & 30 \\
\hline
\end{tabular}

$r_{1} \pm S r_{1}=-0.646 \pm 0.108$

第 10 表 姉妹間に和ける 12 の煩舌的 歯冠幅の相関 $(\mathrm{mm})$

\begin{tabular}{r|r|r|r|r|r|r}
\hline $\mathrm{X}$ & 5 & 6 & 7 & 8 & 9 & 計 \\
\hline 5 & & 1 & & & & 1 \\
6 & 1 & 10 & 7 & & & 18 \\
7 & 1 & 2 & 9 & 2 & & 14 \\
8 & & 1 & 3 & & & 4 \\
9 & & & & & 1 & 1 \\
\hline 計 & 2 & 14 & 19 & 2 & 1 & 38 \\
\hline
\end{tabular}

$\mathrm{r}_{2} \pm \mathrm{S} \mathrm{r}_{2}=0.667 \pm 0.091$
第 11 表 兄妹（弟姉）間に和ける $\mid 2$ の 煩舌的圈冠輻の相関 $(\mathrm{mm})$

\begin{tabular}{r|r|r|r|r|r}
\hline $\mathrm{Y} X$ & 5 & 6 & 7 & 8 & 計 \\
\hline 5 & & 3 & 2 & & 5 \\
6 & & 6 & 14 & 1 & 21 \\
7 & 1 & 12 & 13 & 1 & 27 \\
8 & & 1 & 2 & & 3 \\
\hline 計 & 1 & 22 & 31 & 2 & 56 \\
\hline
\end{tabular}

$\mathrm{r}_{3} \pm \mathrm{Sr}_{3}=0.493 \pm 0.102$

第 12 表 兄弟閪に扣ける 13 の煩舌的 粜冠幅の相関 (mm)

\begin{tabular}{r|r|r|r|r|r|r}
\hline $\mathrm{Y}$ & 6 & 7 & 8 & 9 & 12 & 計 \\
\hline 7 & & 1 & & 2 & & 3 \\
8 & 1 & 3 & 8 & 9 & & 21 \\
9 & & & 3 & 2 & 1 & 6 \\
10 & & & & 1 & & 1 \\
\hline 計 & 1 & 4 & 11 & 14 & 1 & 31 \\
\hline
\end{tabular}

$\mathrm{r}_{1} \pm \mathrm{Sr}_{1}=0.256 \pm 0.171$

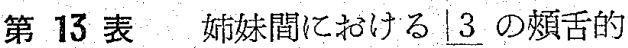
歯冠幅の相関 $(\mathrm{mm})$

\begin{tabular}{r|r|r|r|r}
\hline $\mathrm{Y}$ & 7 & 8 & 9 & 計 \\
\hline 7 & 2 & 3 & & 5 \\
8 & 2 & 14 & 4 & 20 \\
9 & 2 & 5 & 5 & 12 \\
10 & & 1 & & 1 \\
\hline 計 & 6 & 23 & 9 & 38 \\
\hline
\end{tabular}

$\mathrm{r}_{2} \pm \mathrm{Sr}_{2}=0.258 \pm 0.153$

第 14 表 兄妹（弟妏）間に扣ける $\mid 3$ の 煩舌的歯冠幅の相関 $(\mathrm{mm})$

\begin{tabular}{r|r|r|r|r}
\hline $\mathrm{Y} X$ & 7 & 8 & 9 & 計 \\
\hline 6 & 1 & & & 1 \\
7 & 2 & 6 & 2 & 10 \\
8 & 2 & 7 & 12 & 31 \\
9 & & 17 & 8 & 15 \\
\hline 計 & 5 & 30 & 22 & 57 \\
\hline
\end{tabular}

$\mathrm{r}_{3} \pm \mathrm{Sr}_{3}=0.364 \pm 0.115$ 
第 15 表 兄弟間と和ける 4 の煩舌的 畨冠幅の相関 ( $\mathrm{mm}$ )

\begin{tabular}{|c|c|c|c|c|c|}
\hline$Y^{X}$ & 8 & 9 & 10 & 11 & 計 \\
\hline 8 & & & 2 & & 2 \\
\hline 9 & 1 & 2 & 4 & & 7 \\
\hline 10 & & 9 & 8 & 1 & 18 \\
\hline 11 & & 1 & 1 & 1 & 3 \\
\hline 計 & 1 & 12 & 15 & 2 & 30 \\
\hline
\end{tabular}

$\mathrm{r}_{1} \pm \mathrm{Sr}_{1}=0.195 \pm 0.178$

第 16 表 姉妹間に和ける 14 ○頓舌的 类冠幅の相関 $(\mathrm{mm})$

\begin{tabular}{|c|c|c|c|c|}
\hline $\mathrm{Y} X$ & 9 & 10 & 11 & 阡 \\
\hline 8 & 1 & & & 1 \\
\hline 9 & 14 & 8 & & 22 \\
\hline 10 & 3 & 10 & & 13 \\
\hline 11 & & 1 & 1 & 2 \\
\hline 計 & 18 & 19 & 1 & 38 \\
\hline
\end{tabular}

$\mathrm{r}_{2} \pm \mathrm{Sr}_{2}=0.547 \pm 0.115$

第 17 表 完妹 (弟姉) 間に揖ける 14 の 頰舌的歯冠幅の相関 $(\mathrm{mm})$

\begin{tabular}{|c|c|c|c|c|}
\hline $\mathrm{Y} X$ & 9 & 10 & 11 & 計 \\
\hline 7 & & 1 & & 1 \\
\hline 8 & 7 & & & 7 \\
\hline 9 & 7 & 16 & & 23 \\
\hline 10 & 7 & 13 & 4 & 24 \\
\hline 11 & & 1 & & 1 \\
\hline 計 & 21 & 31 & 4 & 56 \\
\hline
\end{tabular}

$\mathrm{r}_{3} \pm \mathrm{Sr}_{3}=0.351 \pm 0.118$

第 18 表 兄弟間に和ける 15 の頓舌的 蒾冠幅の相関 $(\mathrm{mm})$

\begin{tabular}{r|r|r|r|r|r}
\hline $\mathrm{X}$ & 8 & 9 & 10 & 11 & 計 \\
\hline 8 & & 1 & 1 & & 2 \\
9 & & 5 & 4 & 1 & 10 \\
10 & 1 & 5 & 5 & 3 & 14 \\
11 & & 2 & 1 & 2 & 5 \\
\hline 計 & 1 & 13 & 11 & 6 & 31 \\
\hline
\end{tabular}

$\mathrm{r}_{1} \pm \mathrm{Sr}_{1}=0.232 \pm 0.172$
第 19 表 姉妹間と扑ける 15 の頓舌的 歯冠幅の相関 $(\mathrm{mm})$

\begin{tabular}{r|r|r|r|r|r}
\hline $\mathrm{Y}$ & 8 & 9 & 10 & 11 & 計 \\
\hline 8 & & 4 & & & 4 \\
9 & 2 & 11 & 5 & & 18 \\
10 & & 8 & 6 & 1 & 15 \\
11 & & 1 & 1 & & 2 \\
\hline 謓 & 2 & 24 & 12 & 1 & 39 \\
\hline
\end{tabular}

$\mathrm{r}_{2} \pm \mathrm{Sr}_{2}=0.303 \pm 0.147$

第 20 表 兄妹 (弟姉) 間に打ける 15 の 槙舌的蒾冠幅の相関 $(\mathrm{mm})$

\begin{tabular}{r|r|r|r|r|r|r}
\hline $\mathrm{Y}$ & 8 & 9 & 10 & 11 & 12 & 計 \\
\hline 8 & & 3 & 5 & 1 & & 9 \\
9 & 1 & 11 & 8 & & & 20 \\
10 & 2 & 3 & 15 & 3 & 1 & 24 \\
11 & & & 2 & 1 & & 3 \\
\hline 計 & 3 & 17 & 30 & 5 & 1 & 56 \\
\hline
\end{tabular}

$\mathrm{r}_{3} \pm \mathrm{Sr}_{3}=0.230 \pm 0.127$

第 21 表 兄弟間に打ける 16 の煩舌的 歯冠幅の相関 (mm)

\begin{tabular}{c|c|c|c|c|c}
\hline $\mathrm{Y}$ & 10 & 11 & 12 & 13 & 計 \\
\hline 10 & & & 1 & & 1 \\
11 & 1 & 2 & 3 & 1 & 7 \\
12 & 1 & 6 & 5 & 4 & 16 \\
13 & & 1 & 4 & 2 & 7 \\
\hline 計 & 2 & 9 & 13 & 7 & 31 \\
\hline
\end{tabular}

$\mathrm{r}_{1} \pm \mathrm{Sr}_{1}=-0.390 \pm 0.156$

第 22 表：姉陡間に初ける 16 の煩舌的 歯冠幅の相関 $(\overline{\mathrm{mm}})$

\begin{tabular}{r|r|r|r|r|r}
\hline $\mathrm{Y} X$ & 10 & 11 & 12 & 13 & 計 \\
\hline 10 & & 1 & & & 1 \\
11 & 1 & 7 & 6 & 1 & 15 \\
12 & & 7 & 14 & & 21 \\
\hline 計 & 1 & 15 & 20 & 1 & 37 \\
\hline
\end{tabular}

$\mathrm{r}_{2} \pm \mathrm{Sr}_{2}=0.216 \pm 0.158$ 
$-738-(56)$ 同胞間に和ける蒾冠幅（煩舌的）、日馌の大ささの相関

第 23 表 兄妹 (牙姉) 間に和ける 6 の 頖舌的透冠幅の相関 $(\mathrm{mm})$

\begin{tabular}{r|r|r|r|r|r}
\hline $\mathrm{Y}$ & 10 & 11 & 12 & 13 & 計 \\
\hline 10 & & 1 & 1 & & 2 \\
11 & 1 & 9 & 20 & 3 & 33 \\
12 & & 7 & 9 & 4 & 20 \\
13 & & & & 2 & 2 \\
\hline 計 & 1 & 17 & 30 & 9 & 57 \\
\hline
\end{tabular}

$\mathrm{r}_{3} \pm \mathrm{Sr}_{3}=0.271 \pm 0.123$

第 24 表 㒫弟間とホける17 の煩舌的 齿冠幅の相関 $(\mathrm{mm})$

\begin{tabular}{c|c|c|c|c|c|c}
\hline $\mathrm{Y}$ & 10 & 11 & 12 & 13 & 14 & 計 \\
\hline 10 & & 1 & 1 & & & 2 \\
11 & 1 & 2 & 4 & 1 & & 8 \\
12 & 1 & 2 & 3 & 2 & & 8 \\
13 & & 1 & 2 & 3 & 1 & 7 \\
\hline 計 & 2 & 6 & 10 & 6 & 1 & 25 \\
\hline
\end{tabular}

$\mathrm{r}_{1} \pm \mathrm{Sr}_{1}=0.373 \pm 0.175$
第 25 表 姉妹間に和ける 17 の煩舌的 歯冠幅の相関 $(\mathrm{mm})$

\begin{tabular}{r|r|r|r|r|r|r}
\hline $\mathrm{Y}$ & 9 & 10 & 11 & 12 & 13 & 計 \\
\hline 10 & & & 4 & 1 & & 5 \\
11 & 1 & 2 & 7 & 4 & & 14 \\
12 & & & 5 & 4 & 1 & 10 \\
13 & & & & 1 & & 1 \\
\hline 計 & 1 & 2 & 16 & 10 & 1 & 30 \\
\hline
\end{tabular}

$\mathrm{r}_{2} \pm \mathrm{Sr}_{2}=0.298 \pm 0.169$

第 26 表 兄捇 (弟姉) 間に扣ける 煩舌的歯冠幅の相関 (m m)

\begin{tabular}{c|c|c|c|c|c|r}
\hline $\mathrm{X}$ & 10 & 11 & 12 & 13 & 14 & 計 \\
\hline 10 & 1 & 2 & 5 & 1 & & 9 \\
11 & 1 & 10 & 5 & 4 & 1 & 20 \\
12 & 1 & 4 & 8 & & & 14 \\
13 & & 1 & 2 & & & 3 \\
\hline 計 & 3 & 17 & 20 & 5 & 1 & 46 \\
\hline
\end{tabular}

$\mathrm{r}_{3} \pm \mathrm{Sr}_{3}=-0.038 \pm 0.148$

第 27 表

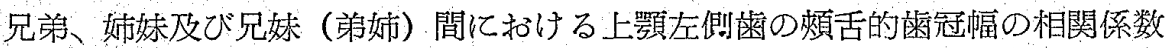

\begin{tabular}{|c|c|c|c|c|c|c|c|c|c|c|}
\hline \multirow{2}{*}{ 上 } & \multirow{2}{*}{ 顎 } & \multirow{2}{*}{ t. } & \multirow{2}{*}{ 側 } & \multirow{2}{*}{ 菌 } & \multicolumn{2}{|c|}{ 男：男 } & \multicolumn{2}{|c|}{ 女：女 } & \multicolumn{2}{|c|}{ 男：男 } \\
\hline & & & & & $\mathrm{N}_{1}$ & $\mathrm{r}_{1} \perp \mathrm{Sr}_{1}$ & $\mathrm{~N}_{2}$ & $\mathrm{r}_{2} \pm \mathrm{Sr}_{2}$ & $\mathrm{~N} 3$ & $\mathrm{r}_{3} \pm \mathrm{Sr}_{1}$ \\
\hline 中。 & & 切 & & 掬 & 30 & $0.044 \pm 0.185$ & 39 & $0.314 \pm 0.146$ & 57 & $0.597 \pm 0.086$ \\
\hline 側 & & 切 & & 電 & 30 & $-0.646 \pm 0.108$ & 38 & $0.667 \pm 0.091$ & 56 & $0.493 \pm 0.102$ \\
\hline 犬 & & & & 霆。 & 31 & $0.256 \pm 0.171$ & 38 & $0.258 \pm 0.153$ & 57 & $0.364 \pm 0.115$ \\
\hline 第 & - & 小 & $E$ & 雪 & 30 & $0.195 \pm 0.178$ & 38 & $0.547 \pm 0.115$ & 56 & $0.351 \pm 0.118$ \\
\hline 第 & $=$ & 小 & $E$ & 歯 & 31 & $0.232 \pm 0.172$ & 39 & $0.303 \pm 0.147$ & 56 & $0.230 \pm 0.127$ \\
\hline 第 & $\rightarrow$ & 大 & $\Theta$ & 栒 & 31 & $-0.390 \pm 0.156$ & 37 & $0.216 \pm 0.158$ & 57 & $0.271 \pm 0.123$ \\
\hline 第 & $=$ & 大 & $E$ & 歯 & 25 & $0.373 \pm 0.175$ & 30 & $0.298 \pm 0.169$ & 46 & $-0.038 \pm 0.148$ \\
\hline
\end{tabular}

頖舌的雬冠幅の相関係数は兄弟力シ-0.646〜0.373、 姉妹は0.216〜0.667、完妹（姉弟）はー0.038〜0.597 でかる
性組合せ別相䦭係数の比較

兄弟と姉妹、兄弟と兄娃（弟姉）及び妏姝之兄妹 (弟姉) の上顎画の頉舌的歯冠幅の相関係数を比べる と、第28表のと扣りである。 
第 28 表 兄弟、姉妹及び兄妹（弟姉）間における上顎左側歯の煩舌的歯冠幅の相関係数の比較

\begin{tabular}{|c|c|c|c|c|c|c|c|c|c|}
\hline \multirow{2}{*}{ 上 } & \multirow{2}{*}{ 顎 } & \multirow{2}{*}{ 左 } & \multirow{2}{*}{ 歯 } & \multicolumn{2}{|c|}{ 男：男一女：女 } & \multicolumn{2}{|c|}{ 男：男一男：女 } & \multicolumn{2}{|c|}{ 女：女一男：女 } \\
\hline & & & & $\mathrm{d}_{1} \pm \mathrm{Sd}_{2}$ & $\mathrm{~d} / \mathrm{Sd}$ & $\mathrm{d}_{2} \pm \mathrm{Sd}_{2}$ & $d / S d$ & $\mathrm{~d}_{3} \pm \mathrm{Sd}_{3}$ & $\mathrm{~d} / \mathrm{Sd}$ \\
\hline 中 & & 切 & 雷 & $-0.270 \pm 0.235$ & -1.148 & $-0.553 \pm 0.204$ & -2.710 & $-0.283 \pm 0.169$ & -1.674 \\
\hline 側 & & 切 & 歯 & $-1.313 \pm 0.141$ & -9.132 & $-1.139 \pm 0.148$ & -7.695 & $0.174 \div 0.137$ & 1.270 \\
\hline 犬 & & & 歯 & $-0.002 \pm 0.229$ & -0.009 & $-0.108 \pm 0.206$ & -0.524 & $-0.106 \pm 0.191$ & -0.554 \\
\hline 第 & - & 小 & 践 & $-0.352 \pm 0.211$ & -1.668 & $-0.156 \pm 0.213$ & -0.732 & $0.196 \pm 0.164$ & 1.195 \\
\hline 第 & 二 & 小曰 & 柴 & $-0.071 \pm 0.226$ & -0.314 & $0.002 \pm 0.214$ & 0.009 & $0.073 \pm 0.194$ & 0.376 \\
\hline 第 & - & 大 $\boxminus$ & 黄 & $-0.606 \pm 0.222$ & -2.729 & $-0.661 \pm 0.198$ & -3.338 & $-0.055 \pm 0.200$ & -0.275 \\
\hline 第 & 二 & 大 $\boxminus$ & 雾 & $0.075 \pm 0.243$ & 0.308 & $0.411 \pm 0.229$ & 1.794 & $0.336 \pm 0.224$ & 1.500 \\
\hline \multicolumn{4}{|c|}{$\begin{array}{l}\mathrm{K}=7 \\
\mathrm{~S}_{\mathrm{Mr}}=0.408\end{array}$} & \multicolumn{2}{|c|}{$\begin{array}{l}\mathrm{Mr} \\
\mathrm{Mr} / \mathrm{S}_{\mathrm{Mr}}=-2.125 \\
\end{array}$} & \multicolumn{2}{|c|}{$\begin{array}{l}\mathrm{Mr}=-1.885 \\
\mathrm{Mr} / \mathrm{S}_{\mathrm{Mr}}=-4.620\end{array}$} & \multicolumn{2}{|c|}{$\begin{array}{l}\mathrm{Mr}=0.263 \\
\mathrm{Mr} / \mathrm{S}_{\mathrm{Mr}}=0.645\end{array}$} \\
\hline
\end{tabular}

a. 兄弟之姉妹の比較

第28表のよ5に、両組合せの相関係数の差に有意戔 性のある荬は、側切歯と第一大日崡で姉炼の方が大で ある。7 歯全般的仙両組合せ間の相関係数を比べる と、 $\mathrm{Mr} / \mathrm{S} \mathrm{Mr}$ がー 5.208 で有意義性の差があり、姉妹 の方が兄弟よりも上顎雨の䨤冠愊（煩舌的）の相哭性 は大である。

b . 兄弟と兄珠（弟执）の比䡆

第28表のように、両組合せの相関係数の差に有意義 性のある霜は、中切速、側切霜と第一大目歯でいずれ も兄妹（弟姉）の方が大である。全般的に両組合せの 相関係数を比べると、 $\mathrm{Mr} / \mathrm{S}_{\mathrm{Mr}}$ がー4.620 で有意学性 の差があり、兄弟（弟姉）の相関性が大である。

\section{c．林捇と兄旂（弟姑）の比較}

第28表のよ5に、両組合せの相関係数の差は、級別 及び全般的 $\left(\mathrm{Mr} / \mathrm{S}_{\mathrm{Mr}}=0.645\right)$ も有意義性の差は なく、両組合せ間には相関性の差はほとんどない。

\section{d. 小 括}

同胞間に和ける上顎菜の頓舌的菡冠幅は、各組合せ とも各菌の相関性はかなりつよいが、性組合せ間で は、兄弟＜姉妹、兄弟<兄妹（弟姉）、姉妹三兄妹(弟 姉）である。兄弟がもつとも小さく、姉妹と兄妹（弟 姉）間の差はほとんどない。

\section{B. 下 顎 歯}

同胞の性組合せ別の下顎左側 7 菌の煩舌的歯冠幅の 相関係数は第29～50表のと扣りである。
第 29 表 兄弟間に㭁引る历 の頓舌的 崡冠幅の相関 $(\mathrm{mm})$

\begin{tabular}{|c|c|c|c|c|c|}
\hline$y^{X}$ & 5 & 6 & 7 & 8 & 計 \\
\hline 5 & & 2 & 1 & & 3 \\
\hline 6 & & 2 & 6 & 1 & 9 \\
\hline 7 & 1 & 7 & 7 & 2 & 17 \\
\hline 8 & 1 & & & & 1 \\
\hline 計 & 2 & 11 & 14 & 3 & 30 \\
\hline
\end{tabular}

$\mathrm{r}_{1} \pm \mathrm{Sr}_{1}=-0.033 \pm 0.185$

第 30 表 姉妹間に打ける历顧舌的 歯冠楅の相関 $(\mathrm{mm})$

\begin{tabular}{r|r|r|r|r|r|r}
\hline $\mathrm{Y} X$ & 5 & 6 & 7 & 8 & 9 & 計 \\
\hline 5 & & 4 & & & & 5 \\
6 & & 14 & 4 & 1 & 1 & 21 \\
7 & 1 & 2 & 4 & 2 & & 8 \\
8 & 1 & & 2 & & & 2 \\
\hline 計 & 2 & 20 & 10 & 3 & 1 & 36 \\
\hline
\end{tabular}

$\mathrm{r}_{2} \pm \mathrm{Sr}_{2}=0.451 \pm 0.134$

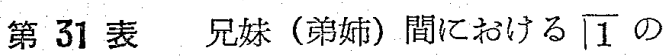
頓舌的歯冠幅の相関 $(\mathrm{mm})$

\begin{tabular}{r|r|r|r|r|r|r}
\hline $\mathrm{X}$ & 5 & 6 & 7 & 8 & 9 & 計 \\
\hline 5 & & 3 & 1 & & & 4 \\
6 & 1 & 17 & 11 & 2 & & 31 \\
7 & & 9 & 6 & 1 & 1 & 17 \\
8 & & 2 & 1 & & 1 & 4 \\
\hline 計 & 1 & 31 & 19 & 3 & 2 & 56 \\
\hline \multicolumn{5}{r}{} \\
\hline
\end{tabular}


第 32 表 兄弟間に和ける 崡冠幅の相関 $(\mathrm{mm})$

\begin{tabular}{|c|c|c|c|c|c|}
\hline $\mathrm{Y} X$ & 5 & 6 & 7 & 8 & 詰立 \\
\hline 5 & & 1 & 1 & & 2 \\
\hline 6 & & 1 & 5 & 1 & 7 \\
\hline 7 & 1 & 2 & 7 & 8 & 18 \\
\hline 8 & $\%$ & 1 & 1 & 1 & 3 \\
\hline 計 & 1 & 5 & 14 & 10 & 30 \\
\hline
\end{tabular}

$\mathrm{r}_{1} \pm \mathrm{Sr}_{1}=-0.179 \pm 0.179$

第 33 表 姉妹間に扔りる $\sqrt{2}$ の頓舌的 歯冠幅の相関 $(\mathrm{mm})$

\begin{tabular}{c|c|c|c|c}
\hline $\mathrm{X}$ & 6 & 7 & 8 & 1 \\
\hline $\mathrm{Y}$ & 6 & & & \\
\hline 5 & 1 & & & 1 \\
6 & 7 & 8 & 1 & 16 \\
7 & 3 & 8 & 2 & 13 \\
8 & & 4 & 1 & 5 \\
9 & & & 1 & 1 \\
\hline 計 & 11 & 20 & 5 & 36 \\
\hline
\end{tabular}

$\mathrm{r}_{2} \pm \mathrm{Sr}_{2}=0.666 \pm 0.093$

第 34 表 兄㛥 (弟姉) 間に括ける 頓舌的歯冠幅の相関 $(\mathrm{mm})$

\begin{tabular}{|c|c|c|c|c|c|c|}
\hline$Y^{X}$ & 5 & 6 & 7 & 8 & 9 & 計 \\
\hline 5 & & 1 & 2 & & & 3 \\
\hline 6 & 1 & 6 & 13 & 1 & & 21 \\
\hline 7 & & 7 & 15 & 4 & 1 & 27 \\
\hline 8 & & 1 & 2 & 1 & & 4 \\
\hline 9 & & & 1 & & & 1 \\
\hline 計 & 1 & 15 & 33 & 6 & 1 & 56 \\
\hline
\end{tabular}

$\mathrm{r}_{3} \pm \mathrm{Sr}_{3}=0.188 \pm 0.130$

第 35 表 兄弟間に打ける $\sqrt{3}$ の頪舌的 雾冠幅の相関 ( $\mathrm{mm}$ )

\begin{tabular}{|r|r|r|r|r|r}
\hline $\mathrm{Y}$ & 6 & 7 & 8 & 9 & 計 \\
\hline 7 & & & 4 & 1 & 5 \\
8 & & 3 & 6 & 7 & 16 \\
9 & 1 & 2 & 3 & 4 & 10 \\
\hline 計 & 1 & 5 & 13 & 12 & 31 \\
\hline
\end{tabular}

$\mathrm{r}_{1} \pm \mathrm{Sr}_{1}=-0.098 \pm 0.180$

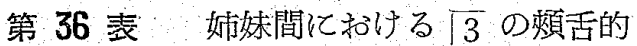
歯冠幅の相関 $(\mathrm{mm})$

\begin{tabular}{r|r|r|r|r|r}
\hline $\mathrm{Y}$ & 7 & 8 & 9 & 10 & 計 \\
\hline 6 & 1 & 1 & & & 2 \\
7 & 4 & 9 & 1 & & 14 \\
8 & 1 & 11 & 1 & & 13 \\
9 & & 2 & 3 & 2 & 7 \\
\hline 計 & 6 & 23 & 5 & 2 & 36 \\
\hline
\end{tabular}

$\mathrm{r}_{2} \pm \mathrm{Sr}_{2}=0.584 \pm 0.111$

第 37 表 兄妹 (弟姉) 間に扔ける $\sqrt{3}$ の 煩舌的歯冠幅の相関 $(\mathrm{mm})$

\begin{tabular}{r|r|r|r|r|r}
\hline $\mathrm{Y}$ & 7 & 8 & 9 & 10 & 計 \\
\hline 6 & & 1 & & & 1 \\
7 & 6 & 7 & 5 & & 18 \\
8 & 6 & 17 & 7 & 1 & 31 \\
9 & & 3 & 2 & & 5 \\
10 & 1 & & & & 1 \\
\hline 計 & 13 & 28 & 14 & 1 & 56 \\
\hline \multicolumn{3}{c}{$\mathrm{r}_{3} \pm \mathrm{Sr}_{3}=0.057 \pm 0.134$} \\
\end{tabular}

第 38 表 兄弟間に䂆ける $\sqrt{4}$ の頓舌的 歯冠幅の相関 $(\mathrm{mm})$

\begin{tabular}{r|r|r|r|r|r}
\hline \hline $\mathrm{Y}$ & 7 & 8 & 9 & 10 & 計 \\
\hline 7 & & & 1 & & 1 \\
8 & 2 & 4 & 4 & & 10 \\
9 & & 11 & 7 & 2 & 20 \\
\hline 計 & 2 & 15 & 12 & 2 & 31 \\
\hline
\end{tabular}

$\mathrm{r}_{1} \pm \mathrm{Sr}_{1}=0.436 \pm 0.147$

第 39 表 姉妹間に扣ける $\sqrt{4}$ の頓舌的 霜冠幅の相関 $(\mathrm{mm})$

\begin{tabular}{r|r|r|r|r}
\hline \hline $\mathrm{Y}$ & 7 & 8 & 9 & 計 \\
\hline 7 & & 5 & & 5 \\
8 & 1 & 15 & 4 & 20 \\
9 & & 3 & 6 & 9 \\
10 & & & 1 & 1 \\
\hline 詁 & 1 & 23 & 11 & 35 \\
\hline
\end{tabular}

$\mathrm{r}_{2} \pm \mathrm{Sr}_{2}=0.510 \pm 0.126$ 
第 40 表 兄妹（弟姉）間に打ける 類舌的歯冠幅の相関 $(\mathrm{mm})$

\begin{tabular}{|r|r|r|r|r|r|r}
\hline $\mathrm{X}$ & 7 & 8 & 9 & 10 & 11 & 1 \\
\hline 7 & & 1 & 2 & & & 3 \\
8 & 1 & 17 & 12 & 1 & & 31 \\
9 & & 12 & 8 & & 1 & 21 \\
\hline 計 & 1 & 30 & 22 & 1 & 1 & 55 \\
\hline
\end{tabular}

$\mathrm{r}_{3} \pm \mathrm{Sr} 3=-0.090 \pm 0.134$

第 41 表 完弟間に捈ける $\longdiv { 5 }$ の煩舌的 歯冠幅の相関 $(\mathrm{mm})$

\begin{tabular}{|c|c|c|c|c|}
\hline$Y X$ & 8 & 9 & 10 & 計 \\
\hline 8 & 2 & 3 & 2 & 7 \\
\hline 9 & 4 & 16 & & 20 \\
\hline 10 & 1 & 2 & & 3 \\
\hline 竐 & 7 & 21 & 2 & 30 \\
\hline
\end{tabular}

$r_{1} \pm \operatorname{Sr}_{1}=-0.335 \pm 0.164$

第 42 表 姉味間に和ける $\longdiv { 5 }$ の煩舌的 䨑冠幅の相関 $(\mathrm{mm})$

\begin{tabular}{r|r|r|r|r|r}
\hline $\mathrm{Y}$ & 7 & 8 & 9 & 10 & 計 \\
\hline 7 & & 1 & & & 1 \\
8 & & 6 & 7 & & 13 \\
9 & 1 & 2 & 14 & & 17 \\
10 & & & 3 & 1 & 4 \\
\hline 許 & 1 & 9 & 24 & 1 & 35 \\
\hline
\end{tabular}

$\mathrm{r}_{2} \pm \mathrm{Sr}_{2}=0.431 \pm 0.139$

第 43 表 兄妹 (弟姉) 間に和ける 5 の 頓舌的䒺冠幅の相関 $(\mathrm{mm})$

\begin{tabular}{r|r|r|r|r|r}
\hline $\mathrm{X}$ & 8 & 9 & 10 & 11 & 計 \\
\hline 7 & 8 & 2 & & & 2 \\
8 & 9 & 11 & 2 & & 21 \\
9 & & 15 & 2 & 1 & 27 \\
10 & & 5 & & & 5 \\
\hline 計 & 17 & 33 & 4 & 1 & 55 \\
\hline
\end{tabular}

$\mathrm{r}_{3} \pm \mathrm{Sr}_{\mathbf{3}}=0.129 \pm 0.133$

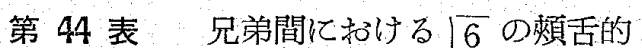
蒾冠幅の相関 $(\mathrm{mm})$

\begin{tabular}{c|c|c|c|c|c|c}
\hline $\mathrm{X}$ & 8 & 10 & 11 & 12 & 13 & 詰 \\
\hline 10 & 1 & & 1 & & & 2 \\
11 & & 1 & 6 & 5 & 1 & 13 \\
12 & & & 5 & 3 & & 8 \\
13 & & & 3 & 2 & & 5 \\
\hline 計 & 1 & 1 & 15 & 10 & 1 & 28 \\
\hline
\end{tabular}

$\mathrm{r}_{1} \pm \mathrm{Sr}_{1}=0.197 \pm 0.184$

第 45 表 姉妹間に杍ける $\sqrt[6]{6}$ の類舌的 歯冠幅の相関 $(\mathrm{mm})$

\begin{tabular}{r|r|r|r|r}
\hline $\mathrm{Y}$ & 10 & 11 & 12 & 計 \\
\hline 10 & & 2 & & 2 \\
11 & 1 & 12 & 6 & 19 \\
12 & & 6 & 6 & 12 \\
\hline 計 & 1 & 20 & 12 & 33 \\
\hline
\end{tabular}

$\mathrm{r}_{2} \pm \mathrm{Sr}_{2}=0.269 \pm 0.163$

第 46 表 兄妹（弟姉）間に扔ける 16 の 頓活的歯冠幅の相関 $(\mathrm{mm})$

\begin{tabular}{r|r|r|r|r|r}
\hline \hline $\mathrm{X}$ & 10 & 11 & 12 & 13 & 計 \\
\hline 7 & & 1 & & & 1 \\
10 & & 2 & 2 & & 4 \\
11 & 1 & 14 & 10 & 3 & 28 \\
12 & & 9 & 10 & 1 & 20 \\
\hline 計 & 1 & 26 & 22 & 4 & 53 \\
\hline
\end{tabular}

$\mathrm{r}_{3} \pm \mathrm{Sr}_{3}=0.499 \pm 0.104$

第 47 莣曾間に抽けっ $\sqrt{7}$ の煩舌的 歯冠幅の相関 $(\mathrm{mm})$

\begin{tabular}{r|r|r|r|r|r|r}
\hline $\mathrm{Y} \mathrm{X}$ & 9 & 10 & 11 & 12 & 13 & 計 \\
\hline 10 & 1 & 4 & 2 & & & 7 \\
11 & & 3 & 6 & 5 & & 14 \\
12 & & & 2 & 1 & 1 & 4 \\
\hline 詰 & 1 & 7 & 10 & 6 & 1 & 25 \\
\hline
\end{tabular}

$\mathrm{r}_{1} \pm \mathrm{Sr}_{1}=-0.211 \pm 0.194$ 
第 48 表 姉妹間に扣ける 齿冠幅の相関 $(\mathrm{mm})$

\begin{tabular}{|c|c|c|c|c|}
\hline $\mathrm{Y}$ & 10 & 11 & 12 & 計 \\
\hline 9 & 1 & & & 1 \\
\hline 10 & 7 & 5 & & 12 \\
\hline 11 & 5 & 8 & 2 & 15 \\
\hline 12 & & 2 & & 2 \\
\hline 13 & & 1 & & 1 \\
\hline 語 & 13 & 16 & 2 & 21 \\
\hline
\end{tabular}

第 49 䘚 兄妹 (弟姉) 間に和ける $\overline{7} の$ 顂舌的䨑冠幅の相関 $(\mathrm{mm})$

\begin{tabular}{r|r|r|r|r}
\hline $\mathrm{X}$ & 10 & 11 & 12 & 計 \\
\hline 9 & & 1 & 3 & 1 \\
10 & 4 & 11 & 5 & 18 \\
11 & 5 & 11 & 2 & 21 \\
12 & 2 & 1 & & 5 \\
\hline 計 & 11 & 24 & 10 & 45 \\
\hline
\end{tabular}

$\mathrm{r}_{3} \pm \mathrm{Sr}_{3}=-0.014 \pm 0.150$

$\mathrm{r}_{2} \pm \mathrm{Sr}_{2}=0.381 \pm 0.155$

第 50 表

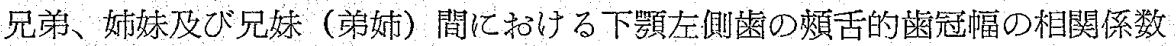

\begin{tabular}{|c|c|c|c|c|c|c|c|c|c|c|}
\hline \multirow{2}{*}{ 下 } & \multirow{2}{*}{ 顎 } & \multirow{2}{*}{ 左 } & \multirow{2}{*}{ 倛 } & \multirow{2}{*}{ 歯 } & \multicolumn{2}{|r|}{ 男：男 } & \multicolumn{2}{|c|}{ 女 : 女 } & \multicolumn{2}{|c|}{ 男 : 女 } \\
\hline & & & & & $\mathrm{N}_{1}$ & $\mathrm{r}_{1} \pm \mathrm{S} \mathrm{r}_{1}$ & $\mathrm{~N}_{2}$ & $r_{2} \pm \mathrm{Sr}_{2}$ & $\mathrm{Ns}$ & $\mathrm{r}_{3} \pm \mathrm{Sr}_{3}$ \\
\hline 中 & & 切 & & 歯 & 30 & $-0.033 \pm 0.185$ & 36 & $0.451 \pm 0.134$ & 56 & $0.014 \pm 0.134$ \\
\hline 側 & & 切 & & 粚 & 30 & $-0.179 \pm 0.179$ & 36 & $0.666 \pm 0.093$ & 56 & $0.188 \pm 0.130$ \\
\hline 犬 & & & & 歯 & 31 & $-0.098 \pm 0.180$ & 36 & $0.584 \pm 0.111$ & 56 & $0.057 \pm 0.134$ \\
\hline 第 & - & 小 & $\Theta$ & 歯 & 31 & $0.436 \pm 0.147$ & 35 & $0.510 \pm 0.126$ & 55 & $-0.090 \pm 0.134$ \\
\hline 第 & $\Rightarrow$ & 小 & $\theta$ & 雬 & 30 & $-0.335 \pm 0.164$ & 35 & $0.431 \pm 0.139$ & 55 & $0.129 \pm 0.133$ \\
\hline 第 & $\rightarrow$ & 大 & 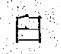 & 齒 & 28 & $0.197 \pm 0.184$ & 33 & $0.269 \pm 0.163$ & 53 & $0.499 \pm 0.104$ \\
\hline 第 & $=$ & 大 & $\theta$ & 1: & 25 & $-0.211 \pm 0.194$ & 31 & $0.381 \pm 0.155$ & 45 & $-0.014 \pm 0.150$ \\
\hline
\end{tabular}

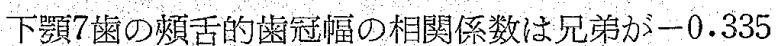
〜0.436、林妹は 0.269〜0.666、兄妹（弟姉）は一 $0.090 \sim 0.499$ である。
性組合せ则相関係数の比較

兄弟と姉妹、兄弟と兄妹（弟姉）及び姉妹と兄妹 (弟姉) の下顎菌の煩舌的崡冠幅の相関係数を比べる と第51表のと挔りである。

第 51 表

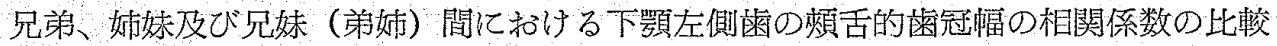

\begin{tabular}{|c|c|c|c|c|c|c|c|c|c|c|}
\hline \multirow{2}{*}{ T } & \multirow{2}{*}{\multicolumn{3}{|c|}{ 䫟 左 側 }} & \multirow{2}{*}{ 歯 } & \multicolumn{2}{|c|}{ 男：男一女：女 } & \multicolumn{2}{|c|}{ 男：男一男：女 } & \multicolumn{2}{|c|}{ 女：女一男：女 } \\
\hline & & & & & $\mathrm{d}_{1} \pm \mathrm{Sd}_{2}$ & $\mathrm{~d} / \mathrm{Sd}$ & $\mathrm{d}_{2} \pm \mathrm{Sd}_{2}$ & $\mathrm{~d} / \mathrm{Sd}$ & $\mathrm{d}_{3} \pm \mathrm{Sd}_{3}$ & $\mathrm{~d} / \mathrm{Sd}$ \\
\hline 中 & & 切 & & 歯 & $-0.484 \pm 0.229$ & -2.113 & $-0.047 \pm 0.229$ & -0.205 & $0.437 \pm 0.189$ & 2.312 \\
\hline 側 & & 切 & & 歯 & $-0.845 \pm 0.201$ & -4.203 & $-0.367 \pm 0.221$ & -1.660 & $0.478 \pm 0.159$ & 3.006 \\
\hline 犬 & & & & 菌 & $-0.682 \pm 0.211$ & -3.232 & $-0.155 \pm 0.224$ & -0.691 & $0.527 \pm 0.174$ & 3.208 \\
\hline 第 & - & 小 & 日 & 歯 & $-0.074 \pm 0.193$ & -0.383 & $0.526 \pm 0.199$ & 2.643 & $0.600 \pm 0.184$ & 3.260 \\
\hline 第 & 二 & 小 & E. & 歯 & $-0.766 \pm 0.215$ & -3.562 & $-0.464 \pm 0.211$ & -2.199 & $0.302 \pm 0.192$ & 1.572 \\
\hline 第 & 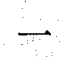 & 大 & $\Theta$ & 崡 & $-0.068 \pm 0.246$ & -0.276 & $-0.302 \pm 0.211$ & -1.431 & $-0.230 \pm 0.193$ & -1.191 \\
\hline 第 & $=$ & 大 & $\Theta$ & 曾 & $-0.592 \pm 0.248$ & -2.387 & $-0.197 \pm 0.245$ & -0.804 & $0.395 \pm 0.216$ & 1.828 \\
\hline \multicolumn{4}{|c|}{$\begin{array}{l}\mathrm{K}=7 \\
\mathrm{~S}_{\mathrm{Mr}}=0.408\end{array}$} & & \multicolumn{2}{|c|}{$\begin{array}{l}\mathrm{Mr}=-2.308 \\
\mathrm{Mr} / \mathrm{S}_{\mathrm{Mr}}=-5.657\end{array}$} & \multicolumn{2}{|c|}{$\begin{array}{l}\mathrm{Mr}=-0.621 \\
\mathrm{Mr} / \mathrm{S}_{\mathrm{Mr}}=-1.522\end{array}$} & \multicolumn{2}{|c|}{$\begin{array}{l}\mathrm{Mr}=1.974 \\
\mathrm{Mr} / \mathrm{S}_{\mathrm{Mr}}=4.838\end{array}$} \\
\hline
\end{tabular}

a. 兄利と姉姝の比較

第51表のように、雨組合せの相関係数の差に有意義 性のある雪は、第一小囦函と第一大曰歯を除いた他の 5 歯にあり、いずれも㛦妹力大である。全般的に差を 比べると、 $\mathrm{Mr} / \mathrm{S}_{\mathrm{Mr}}$ が-5.657 で有意義性の差があり、
姉妹か元弟よりも下顎菡の煩舌的䠛冠幅の相関性は大 である。

\section{b. 兄弟と见妹（弟峬）の比較}

第51表の如く、雨組合せの相関係数の差に有意義性 のあるのは、第一、第二小罒堖で前者は兄第、後者は 
兄妹 (弟姉) が大である。全般的にて両組合せの相関係 数を比べると、 $\mathrm{Mr} / \mathrm{S}_{\mathrm{Mr}}$ がー1.522 で有意義性の差は ないが、やや兄妹 (弟姉) が大である。

c. 姉妹と兄妹 (弟姉) の比較

第51表のように、再組合せの相関係数の差に有意義 性のあるものは、中切歯、側切雪、犬歯、第一小曰歯 でいずれも峬妹が大である。全般的て両組合せの相関 係数を比へると、 $\mathrm{Mr} / \mathrm{S}_{\mathrm{Mr}}$ か 4.838 で有意義性の差が あり、姉妹の相関性が大である。

d. 小 括

同胞の性組合せ別下顎左側 7 菡の頓舌的崡䇝幅の相 関係数は、兄第 <姉姝 >兄妹（弟姉）、兄禹 $\leqslant$ 兄妹 (弟姉) で姉妹の相関性がもつとも大、ついで兄妹 (弟姉)、兄弟の順に小さい。

\section{III类 列 弓 周 長}

画列弓周長について、荷宮 ${ }^{18)}$ は受侀精溥凹人を測計 し、むた漞子間の鮆列马周長の類似性を 発表してい る。釉池199姫島、日出、高城及び木浦木などの住民 について発表した。

\section{1. 男と女の雪列弓周長の比較}

第52表のと拈りで、男の上㠓歯列弓周長は平均 91.32 $\mathrm{mm}$ 、下顎歯列马固長は平均 $76.61 \mathrm{~mm}$ 、女では上頢 が平均 $88.80 \mathrm{~mm}$ 、下顎は平均 $75.98 \mathrm{~mm}$ で、男女とも に上顎が下顎より大きく、男女間の差を比べると、上 顎に有意義性の差があり、男の上顎雪列马周長は女の それよりも大である。下顎では男文間の差は有意義性 の差が沶い。
第 52 表

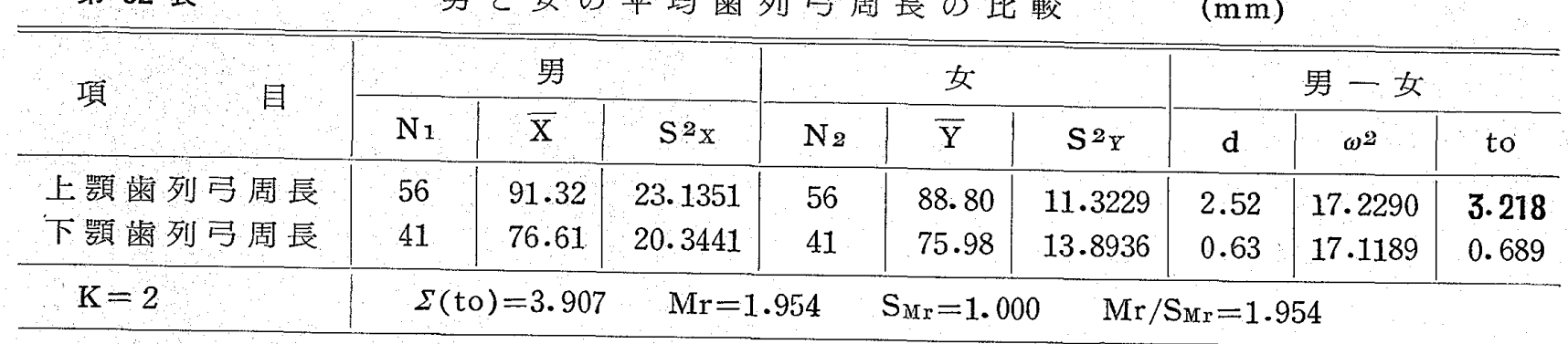

\section{2. 同胞間における柬列局周長の相関係数}

兄弟、姉妹及び兄妹（弟姉）各組合せ内の上、下顎

第 53 表 兄弟間々扣ける上顎崡列号周長 (mm) の相関

\begin{tabular}{|c|c|c|c|c|c|c|c|c|c|c|c|c|c|c|c|}
\hline$Y \mathrm{X}$ & 84 & 85 & 86 & $87 \mid$ & 88 & 89 & 90 & & & & 96 & 97 & & 103 & 計 \\
\hline 81 & & & & 1 & & & & & & & & & & & 1 \\
\hline 84 & & 1 & & & 1 & & & & & & 1 & & & & 3 \\
\hline 85 & & & 1 & & & & & & & & & & & & 1 \\
\hline 86 & & & & & 1 & & & & & & & & & & 1 \\
\hline 87 & 1 & 1 & 1 & & & & & & & & & & & & 3 \\
\hline 88 & & & & & & 1 & 1 & & & & & & & & 2 \\
\hline 89 & & & & & & & & 1 & & & & & & & 1 \\
\hline 90 & 1 & & & & & & & & & & & & & & 1 \\
\hline 91 & 1 & $\therefore$ & & & & & & & 1 & & & & & & 2 \\
\hline 92 & & 1. & & & & & 1 & & 1 & 1 & & & & & 4 \\
\hline 93 & 1 & 1 & & & & & & & & & & 1 & & & 3 \\
\hline 94 & & & & & & & 1 & & & & & & & & 1 \\
\hline 95 & & & & 1 & & 1 & & 1 & & & & & & & 3 \\
\hline 96 & & & & & & & & 1 & & & 1 & & 2 & & 4 \\
\hline 103 & & & & & & & & & & & & & & 1 & 1 \\
\hline 計 & 4 & 4 & 2 & 2 & 2 & 2 & 3 & 3 & 2 & 1 & 2 & 1 & 2 & 1 & 31 \\
\hline
\end{tabular}

歯列甹周長の相関表と相関係数は、第53〜 59表のと柱 りである。

第 54 表 姉妹間に扣ける上頡電列弓周長 $(\mathrm{mm})$ の相関

\begin{tabular}{|c|c|c|c|c|c|c|c|c|c|c|c|c|c|}
\hline $\mathrm{Y} X$ & 83 & 84 & 85 & 86 & 87 & 88 & 89 & 90 & 91 & 92 & 93 & 96 & 計 \\
\hline 82 & 1 & & & & & & & & & & & & 1 \\
\hline 83 & & & & & & & & & & & & 1 & 1 \\
\hline 84 & 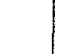 & & 1 & & & 1 & & & & & & & 2 \\
\hline 85 & 1 & & & & 1 & & & & & & & & 2 \\
\hline 86 & & & & & & 1 & & & & & & & 1 \\
\hline 87 & 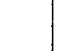 & 2 & & & & & & 2 & & 1 & 1 & & 6 \\
\hline 89 & 2 & & 1 & & 1 & & & & & 2 & 1 & & 7 \\
\hline 90 & . & & & & & & 1 & & & 1 & & & 2 \\
\hline 91 & 1 & & & & & & & 1 & & & 1 & & 3 \\
\hline 92 & & & & 1 & & & & & 1 & & & & 2 \\
\hline 93 & 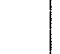 & & & & & 1 & & 1 & & & & & 2 \\
\hline 94 & 1 & & & & & & & & 1 & & 1 & & 3 \\
\hline 96 & & & & & & & 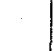 & & & 3 & 1 & & 4 \\
\hline 100 & & & & & & & & & & 1 & & & 1 \\
\hline 101 & & & & & & & 1 & & & & & & 1 \\
\hline 棓 & 6 & 2 & 2 & 1 & 2 & 3 & 2 & 4 & 2 & 8 & 5 & 1 & 38 \\
\hline
\end{tabular}


$-744-（ 62) \quad$ 同胞間に打ける歯冠幅（頓舌的）、篮の大きさの相関

第 55 表

兄妹（弟姉）間に扣ける上顎虚列弓周長 $(\mathrm{mm})$ の相関

\begin{tabular}{|c|c|c|c|c|c|c|c|c|c|c|c|c|c|c|c|c|c|c|c|c|}
\hline$y^{X}$ & 82 & 83 & 85 & 86 & 87 & 88 & 89 & 90 & 91 & 92 & 93 & 94 & 95 & 96 & 97 & 98 & 100 & 101 & 105 & 計 \\
\hline 82 & & 1 & & & & 1 & & & & & & & & & & & & & & 2 \\
\hline 83 & 1 & & & & & & & & & & & & & & & & & & & 1 \\
\hline 84 & & & & & & & & & 1 & & & & & & & & & & & 1 \\
\hline 85 & & & & 1 & 1 & 1 & & & & & & & & & & & & & & 5 \\
\hline 86 & & 1 & 1 & & & & & & 1 & & & 1 & 2 & & & & & & & 4 \\
\hline 87 & & & & & 1 & & 1 & 2 & & 1 & & 2 & & & 2 & & & & & 9 \\
\hline 88 & & & 1 & 1 & & & 1 & & 1 & & 3 & & & & & & & & & 7 \\
\hline 89 & & & & & 1 & 1 & & & & & & & 1 & & & & 1 & & & 4 \\
\hline 90 & & & & 2 & & 1 & & & 1 & & & & & 2 & & & & & & 6 \\
\hline 91 & & & & & & & 1 & 1 & 1 & 1 & & & & & 1 & & & & & 5 \\
\hline 92 & & & & & & & & 1 & & & & & & & & 1 & & & 1 & 3 \\
\hline 93 & & & & & & & & 1 & 1 & & & 1 & 1 & & & & 1 & & & 5 \\
\hline 94 & & & & & & & & & & 1 & & & & & & & & & & 1 \\
\hline 95 & & & & & & & & & & & & & & & & & & 1 & & 1 \\
\hline 96 & & & & & 1 & & & & & & & & & & & & & & & 1 \\
\hline 97 & & 1 & 1 & & & & & & 1 & & & & & & & & 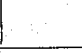 & & & 1 \\
\hline 話 & 1 & 2 & 2 & 4 & 4 & 4 & 3 & 5 & 7 & 3 & 3 & 4 & 4 & 2 & 3 & 1 & 2 & 1 & 1 & 56 \\
\hline
\end{tabular}

$\mathrm{r}_{3} \pm \mathrm{Sr}_{3}=0.363 \pm 0.117$

第 56 表 兄弟間に捛ける下顎荬列弓周長

$(\mathrm{mm})$ の相関

\begin{tabular}{|c|c|c|c|c|c|c|c|c|c|c|c|c|c|}
\hline $\mathrm{Y}^{\mathrm{X}}$ & 70 & 71 & 72 & 74 & 75 & 76 & & 78. & & 30 & & & 33 計 \\
\hline 69 & & & & & & & & & 1 & & & & 1 \\
\hline 72 & & 1 & & & & & & & & & & & 1 \\
\hline 74 & & 1 & 2 & & & & & & & & & & 3 \\
\hline 75 & & & & 2 & & & & & 1 & 1 & & & 4 \\
\hline 76 & & & & & 1 & & & & & & & & 1 \\
\hline 77 & 1 & & & & & 1. & & & & & & & 2 \\
\hline 78 & & & & 1 & 2 & & & 1 & & 1 & & & 5 \\
\hline 79 & & & & & & & & & 1 & 1 & & & 2 \\
\hline 80 & & & 1 & & & & 1 & & & & & 1 & 3 \\
\hline 81 & & & & & & & & & & & 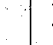 & 1 & 1 \\
\hline 82 & & & & & & & & & & & 1 & & 1 \\
\hline 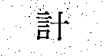 & 1 & 2 & 3 & 3 & 3 & 1 & 1 & 1 & 3 & 3 & 1 . & \begin{tabular}{l|l}
1 & 1
\end{tabular} & 124 \\
\hline
\end{tabular}

$r_{1} \pm \mathrm{Sr}_{1}=0.411 \pm 0.173$
第 57 表 姉妹間に扣ける下顎崡列弓周長

$(\mathrm{mm})$ の相関

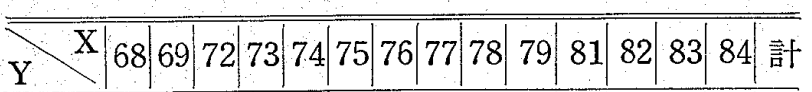

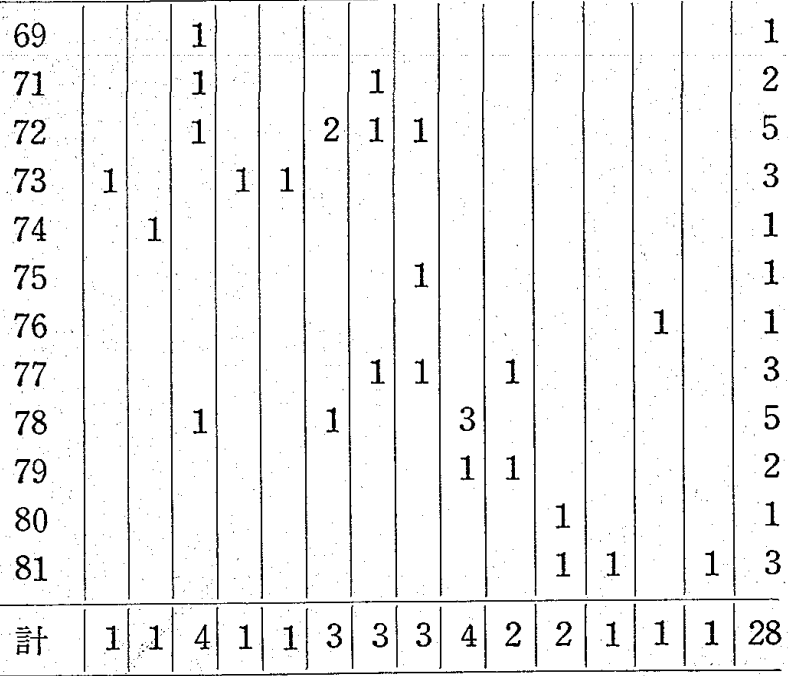

$\mathrm{r}_{2} \pm \mathrm{Sr}_{2}=0.753 \pm 0.083$ 
第 58 表 兄妹（弟姉）閪に扣ける下顎米列 马周長 $(\mathrm{mm})$ の相関

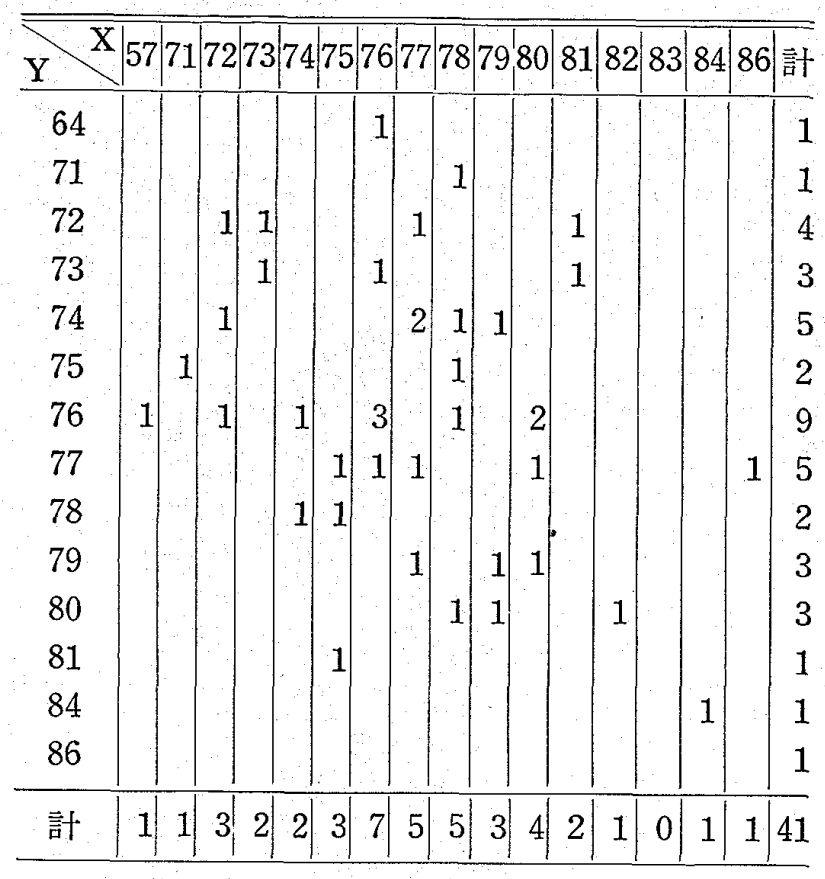

$\mathrm{r}_{3} \pm \mathrm{Sr} 3=0.180 \pm 0.153$
上顎と下顎の歯列局長の相関係数は、兄弟力之0. 540 と 0.411 、姉妹か 0.323 と 0.753 、兄第（弟姉）かシ0.363 と0.180である。

\section{3. 同胞間における㐘列弓周長の相関係数の比較}

a. 兄弟と姉妹の比較

第60袁のと损りで、上、下顎とも有意義性の差がな く、西組合さの相関性の差は上顎は兄弟の相関性がわ ずかけ大きく、下顎は姉妹の相関性ががり大であ b。

\section{b. 兄弟と兄妹（䏲姉）の比較}

第60表のように、両組合せの相関係数の有意義性の. 差は、級別、全般的 $\left(\mathrm{Mr} / \mathrm{S}_{\mathrm{Mr}}=1.009\right)$ にない。 両組合せ間の相関性の差は著しくないが兄妹（弟姉） の相関性が兄弟の相関性よりもわずかに小である。

c . 姉妹と兄妹 (弟姉) の上較

第60表のように、両組合せの相関係数の有意義性の 巠は、下顎雨列呞長にあり、姉妹の相関が大であ る。

\section{d. 小 括}

同胞間に扑る上、下顎雪列弓周長の相関性は、各

第 59 表 兄弟、妨妹及び兄妹（弟姉）間に㜾ける宩列周長の相関係数

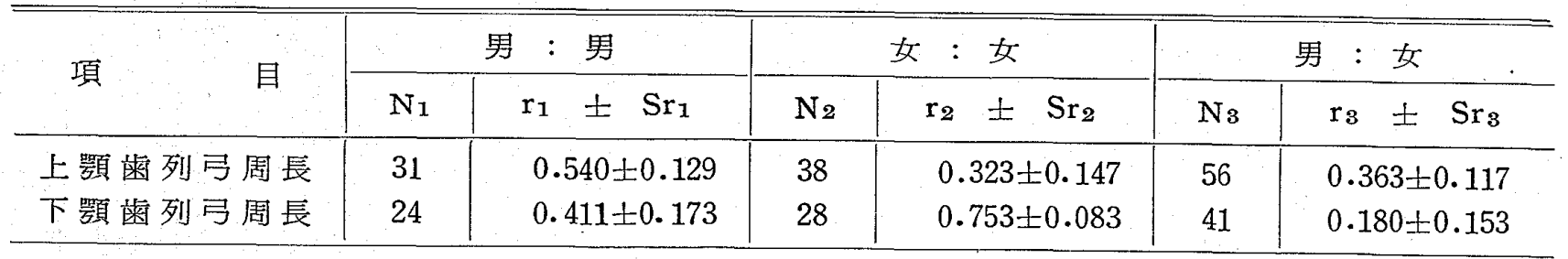

第 60 表

\begin{tabular}{|c|c|c|c|c|c|c|}
\hline \multirow{2}{*}{ 項 } & \multicolumn{2}{|c|}{ 男：男一女：女 } & \multicolumn{2}{|c|}{ 男：男一男：女 } & \multicolumn{2}{|c|}{ 女：女一男：女 } \\
\hline & $\mathrm{d}_{1} \pm S \mathrm{Sd}_{1}$ & $\mathrm{~d} / \mathrm{Sd}$ & $\mathrm{d}_{2} \pm \mathrm{Sd}_{2}$ & $\mathrm{~d} / \mathrm{Sd}$ & $\mathrm{d}_{3} \pm \mathrm{Sd}_{3}$ & $d / S d$ \\
\hline 上顎霜列弓周長 & $0.217 \pm 0.195$ & 1.112 & $0.177 \pm 0.174$ & 1.017 & $-0.040 \pm 0.188$ & -0.212 \\
\hline 下顎雪列弓周長 & $-0.342 \pm 0.192$ & -1.781 & $0.231 \pm 0.231$ & 1.000 & $0.573 \pm 0.174$ & 3.293 \\
\hline $\begin{array}{l}\mathrm{K}=2 \\
\mathrm{~S}_{\mathrm{Mr}}=1.000\end{array}$ & \multicolumn{2}{|c|}{$\begin{array}{l}\mathrm{Mr}=-0.335 \\
\mathrm{Mr} / \mathrm{S}_{\mathrm{Mr}}=-0.335\end{array}$} & \multicolumn{2}{|c|}{$\begin{array}{l}\mathrm{Mr} \quad=1.009 \\
\mathrm{Mr} / \mathrm{S}_{\mathrm{Mr}}=1.009\end{array}$} & \multicolumn{2}{|c|}{$\begin{array}{l}\mathrm{Mr} \quad=1.541 \\
\mathrm{Mr} / \mathrm{S}_{\mathrm{Mr}}=1.541\end{array}$} \\
\hline
\end{tabular}

組合せ間の差に有意義性がないが、上顎では兄弟の相 関性が姉妹、兄妹（弟姉）よりわずが纪大きく、姉姝 と兄妹（弟姉）との差はほとんどない。下顎では姉妹 がもつとも大きく、兄弟、兄姝（弟姉）の順に小さい。

IV 口蓋弓隆長

口监弓隆長は口蓋の左右的発育状態を示すもので、 口蓋粘膜面にそうて口培の左右的長さで、測計部は犬 歯部、第一小曰歯部、第二小曰霜部、第一大曰歯部で
ある。また口蓋正中縫合線の長さについて、同胞間に 扣ける相関係数を比較した。

荷宮 ${ }^{20)}$ は満洲人、受籼精薄囚人 ${ }^{19}$ 、、親子などについ

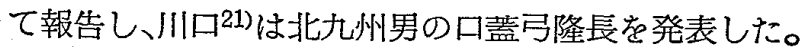

\section{1. 男と女の口蓋弓隆長、口蓋正中縫合線の}

\section{長さの比較}

男と女の口蓋引隆長及び口蓋正中縫合線の長さを比 べると、第61表のと和りである。 


\section{- $746-(64)$ 同胞間に执ける楼冠幅 (煩舌的)、口蓋の大ささの相関}

第 61 表 男と女の平均口笽宁隆の長さの比較

(im)

\begin{tabular}{|c|c|c|c|c|c|c|c|c|c|}
\hline \multirow{2}{*}{ 項 } & \multicolumn{3}{|c|}{ 男 } & \multicolumn{3}{|c|}{ 女 } & \multicolumn{3}{|c|}{ 男一女 } \\
\hline & $\mathrm{N}_{1}$ & $\overline{\mathrm{X}}$ & $S^{2} \mathrm{X}$ & $\mathrm{N}_{2}$ & $\overline{\mathrm{Y}}$ & $S^{2} Y$ & $\mathrm{~d}$ & $\omega^{2}$ & to \\
\hline 大雪部口篕弓隆長 & 57 & 27.19 & 3.6240 & 57 & 26.10 & 3.2040 & 1.09 & 3.4140 & 3.146 \\
\hline 第一小歯部口蓋亏隆長 & 55 & 34.58 & 5.2530 & 55 & 32.25 & 7.4364 & 2.33 & 6.3447 & 4.854 \\
\hline 第二小曰霜部口蓋引隆長 & 55 & 45.58 & 9.6204 & 55 & 43.18 & 9.6010 & 2.40 & 9.6107 & 4.065 \\
\hline 第一大曰雬部口蓋弓隆長 & 57 & 50.31 & 12.9379 & 57 & 48.09 & 14.8355 & 1.22 & 13.8867 & 1.751 \\
\hline 口蓋正中縫合線の長さ & 57 & 33.58 & 8.8872 & 57 & 32.65 & 5.2681 & 0.93 & 7.0777 & 1.867 \\
\hline$K=5$ & & & & & & 500 & $1 \mathrm{~F} / 5$ & .274 & \\
\hline
\end{tabular}

男女間の有意義性の羑は、犬崡部、第一小曰菡部、 第二小曰歯部にあり、いずれも男か大である。全般的 に男女間の差を比べる、 $\mathrm{Mr} / \mathrm{S}_{\mathrm{Mr}}$ 方 6.274 で有意義 性の差があり、男が女よりもロ蓋局隆長は大である。

\section{2. 同胞間における口蓋弓隆長の相関}

兄弟、姉妹及び兄妹（弟姉）の各組合せ内の口荳习 隆長及び口愠正中縫合線の長さの相関係数は、第62〜 77表のと和りである。

第 62 表 兄弟間に和ける犬画部口蕫马隆 長 $(\mathrm{mm})$ の相関

\begin{tabular}{|c|c|c|c|c|c|c|c|}
\hline $\mathrm{Y} \quad \mathrm{X}$ & 24 & 25 & 26 & 27 & 28 & 29 & 訪 \\
\hline 23 & 1 & & 1 & 1 & & & 3 \\
\hline 25 & & 1 & 2 & & 1 & & 4 \\
\hline 26 & 2 & 1 & 1 & 1 & & & 5 \\
\hline 27 & & 2 & 1 & 2 & 2 & & 7 \\
\hline 28 & 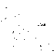 & & 1 & 1 & 1 & 2 & 5 \\
\hline 29 & & & & 2 & & 1 & 3 \\
\hline 30 & & 1 & & & 2 & & 3 \\
\hline 詝 & 3 & 5 & 6 & 7 & 6 & 3 & 30 \\
\hline
\end{tabular}

$\mathrm{r}_{1} \pm \mathrm{Sr}_{1}=0.406 \pm 0.154$
第 63 表 姉妹間に扣ける犬米部口監马 隆長 $(\mathrm{mm})$ )相関

\begin{tabular}{|c|c|c|c|c|c|c|c|c|c|c|}
\hline $\mathrm{Y} \quad \mathrm{X}$ & 19 & 21 & 23 & 24 & 25 & 26 & 27 & 28 & 29 & 計 \\
\hline 20 & & & & 1 & & & & & & 1 \\
\hline 22 & & & & 2 & & & & & & 2 \\
\hline 24 & 1 & & 2 & 1 & & & & & & 4 \\
\hline 25 & & & & 2 & 3 & 3 & & 1 & 1 & 10 \\
\hline 26 & & & & & 1 & 2 & 4 & 2 & 1 & 10 \\
\hline 27 & & 1 & & & 1 & & 1 & 2 & 1 & 6 \\
\hline 28 & & & & & & 1 & 1 & & & 2 \\
\hline 29 & & & & & & & & 1 & 1 & 2 \\
\hline 計 & 1 & 1 & 2 & 6 & 5 & 6 & 6 & 6 & 4 & 37 \\
\hline
\end{tabular}

$\mathrm{r}_{2} \pm \mathrm{Sr}_{2}=0.331 \pm 0.148$

第 64 表 兄妹（弟姉）間に扣ける犬並部 口笽马隆長 $(\mathrm{mm})$ の相関

\begin{tabular}{|c|c|c|c|c|c|c|c|c|c|c|}
\hline$Y \mathrm{X}$ & 23 & 24 & 25 & 26 & 27 & 28 & 29 & 30 & 31 & 計 \\
\hline 22 & & 1 & : & & & & & & & 1 \\
\hline 23 & & & 1 & & 1 & 2 & & & & 4 \\
\hline 24 & & & 1 & & & 4 & & & & 5 \\
\hline 25 & & 1 & 3 & 2 & 1 & 2 & & 1 & & 10 \\
\hline 26 & 1 & & & 4 & 4 & 1 & 1 & & 1 & 12 \\
\hline 27 & 1. & & 5 & 3 & 3 & & 1 & 2 & 1 & 16 \\
\hline 28 & & & & & 2 & & 1 & & & 3 \\
\hline 29 & 1 & & & & 3 & 1 & & & & 5 \\
\hline 31 & & & & & & & & 1 & & 1 \\
\hline 計 & 3 & 2 & 10 & 9 & 14 & 10 & 3 & 4 & 2 & 57 \\
\hline
\end{tabular}

$\mathrm{r}_{3} \pm \mathrm{Sr}_{3}=0.221 \pm 0.127$ 
第 65 表 兄弟間に和ける第一小囦菡部口 蓋宁隆長 $(\mathrm{mm})$ の相関

\begin{tabular}{l|l|l|l|l|l|l|l|l|l|l|l|l}
\hline $\mathrm{Y}$ & $\mathrm{X}$ & 27 & 28 & 30 & 31 & 32 & 33 & 34 & 35 & 36 & 39 & 計 \\
\hline 27 & & & & 1 & & & & & & & 1 \\
28 & 1 & & & & & & & & & & 1 \\
30 & & & & & 1 & & & & & & 1 \\
31 & & & & & & 1 & & & 1 & & 2 \\
32 & & 1 & & & & & 1 & 1 & 1 & & 4 \\
33 & & & & & & 1 & & 1 & & & 2 \\
34 & & & & 2 & & 1 & 2 & & & & 5 \\
35 & & & 2 & & 1 & & & & 3 & & 6 \\
36 & & & 1 & & & & & & & & 1 \\
37 & & 1 & 1 & & & & 1 & & & & 3 \\
38 & & & & & & 1 & & & 1 & & 2 \\
39 & & & & & & & & & 1 & & 1 \\
40 & & & & & & & & & & & \\
41 & & & & & & & & & & & \\
42 & & & & & & & & & & 1 & 1 \\
\hline 計 & 1 & 2 & 4 & 3 & 2 & 4 & 4 & 2 & 7 & 1 & 30 \\
\hline
\end{tabular}

$\mathrm{r}_{1} \pm \mathrm{Sr}_{1}=0.348 \pm 0.163$

第 66 表 姉妹間に扣ける第一小曰崡部口 蓋弓隆長 $(\mathrm{mm})$ の相関

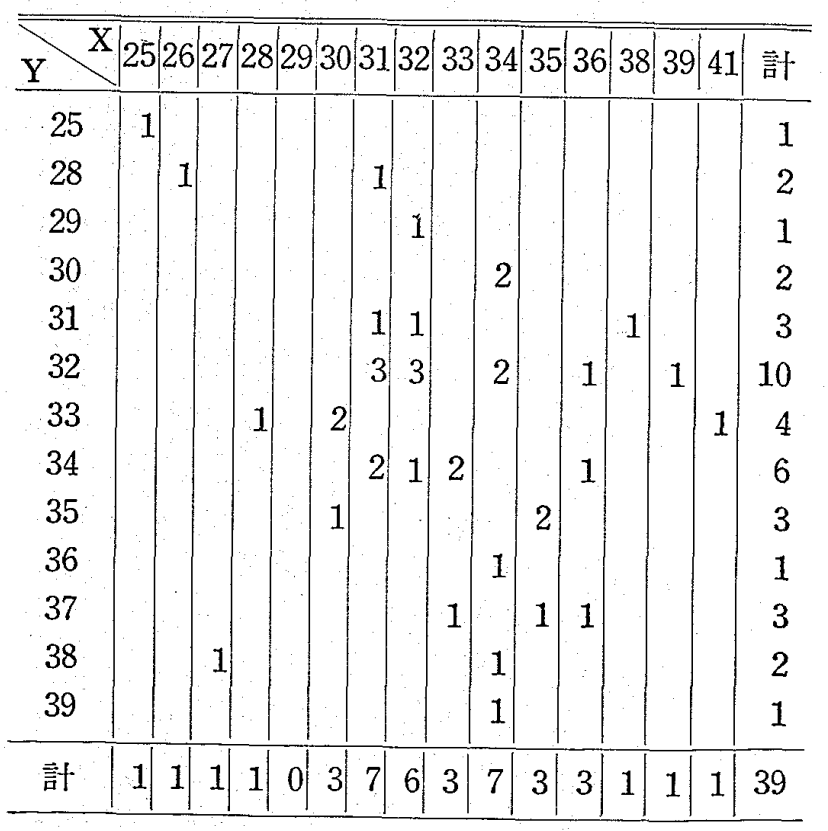

$\mathrm{r}_{2} \pm \mathrm{Sr}_{2}=0.304 \pm 0.147$
第 67 表 兄妹（弟姉）間に扣ける第一小鮆 部口蓋亏隆長 $(\mathrm{mm})$ ）の相関

\begin{tabular}{c|c|c|c|c|c|c|c|c|c|c|c|c|c}
\hline \hline $\mathrm{Y}$ & $\mathrm{X}$ & 30 & 31 & 32 & 33 & 34 & 35 & 36 & 37 & 38 & 39 & 41 & 計 \\
\hline 25 & & & 1 & & & & & & & & & 1 \\
27 & & 1 & & 1 & & 1 & & & & & & 3 \\
28 & & & 1 & & 1 & & & & & & & 2 \\
29 & & & 1 & & 1 & 1 & & & & & & 3 \\
30 & 1 & & & & & 1 & & & 1 & & & 3 \\
31 & 1 & & 1 & 1 & 1 & 2 & & & & & & 6 \\
32 & 1 & 1 & 1 & 3 & 1 & & 1 & 1 & 1 & & & 10 \\
33 & & & & 1 & 2 & & 3 & & & & & 6 \\
34 & & 1 & 1 & 1 & 1 & 3 & & & & 1 & 1 & 9 \\
35 & & & & & & 2 & 1 & 1 & & & & 4 \\
36 & & & 1 & 1 & & 2 & 1 & 1 & & & & 6 \\
37 & & & 1 & & 1 & & & & & & & 2 \\
\hline
\end{tabular}

$\mathrm{r}_{3} \pm \mathrm{Sr} 3=0.280 \pm 0.125$

第 68 表 兄弟間に打ける第二小四歯部 口蓋亏隆長 $(\mathrm{mm})$ の相関

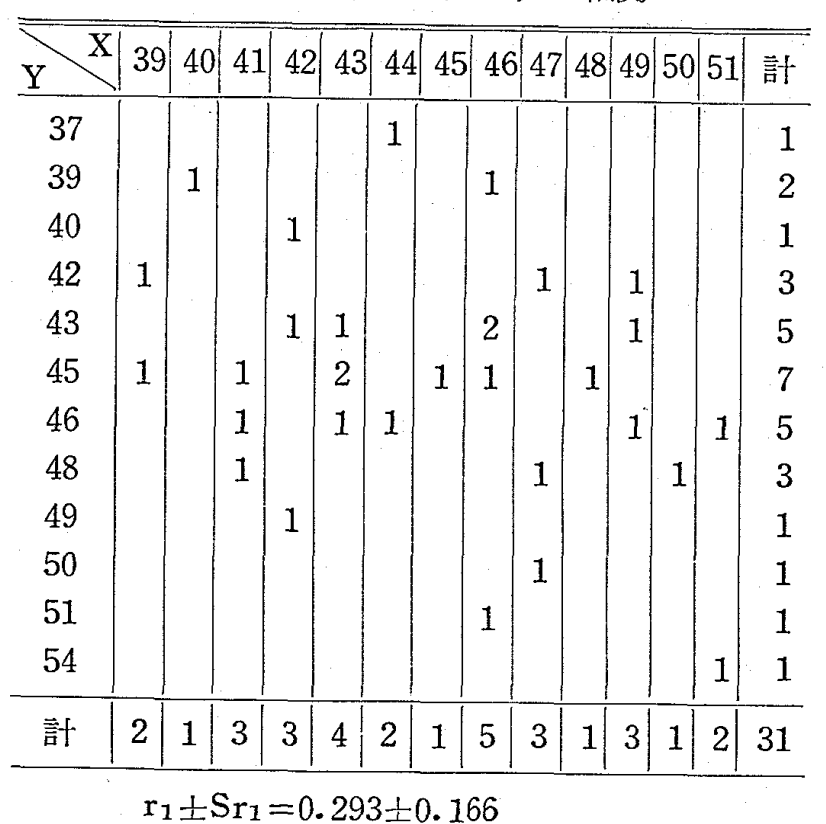

$\mathrm{r}_{1} \pm \mathrm{Sr}_{1}=0.293 \pm 0.166$ 
第 69 表 姉妹間に扣ける第二小臼歯部

口蓋亏隆長 $(\mathrm{mm})$ ) 相関

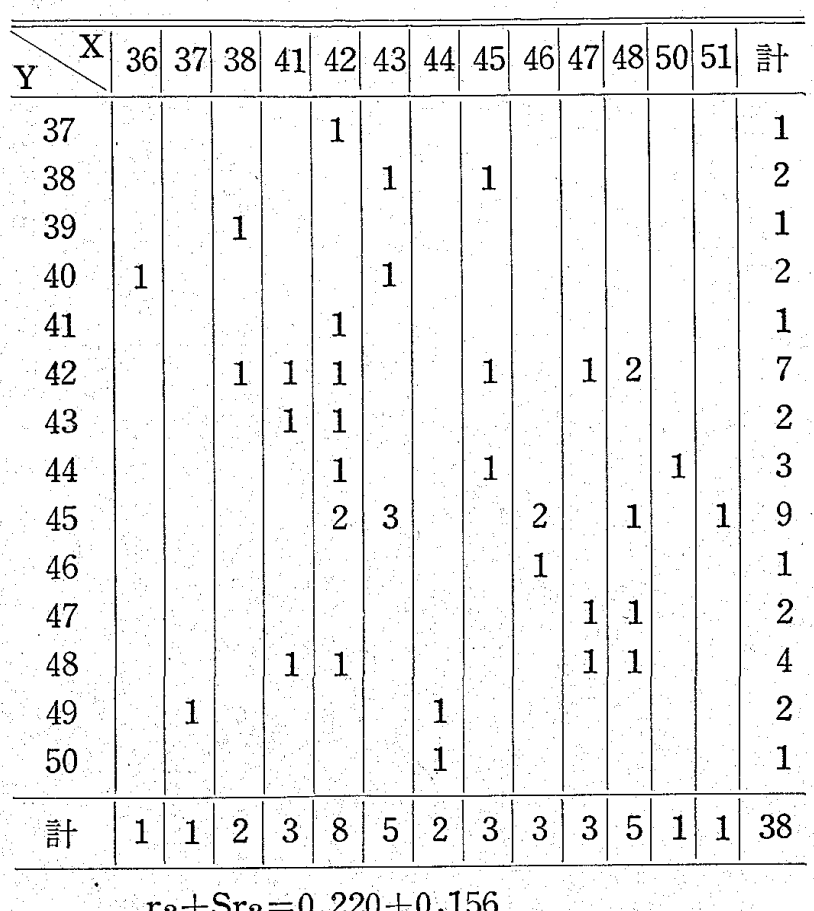

$\mathrm{r}_{2} \pm \mathrm{Sr}_{2}=0.220 \pm 0.156$

第 70 表 兄妹 (弟姉) 間仁和ける第二小曰 霜部口榼亏隆長 $(\mathrm{mm})$ の相関

\begin{tabular}{|c|c|c|c|c|c|c|c|c|c|c|c|c|}
\hline $\mathrm{Y} X$ & $\mid 39$ & 404 & 41 & $\begin{array}{ll}434 \\
\end{array}$ & 445 & & 47 & 48 & 49 & 52 & 54 & 計 \\
\hline 36 & & & 1 & & & & & & & & & 1 \\
\hline 37 & & & & & & 1 & & & & & & 1 \\
\hline 38 & & & & & & & & 1 & & & & 1 \\
\hline 39 & 1 & & 2 & & & & 2 & & 1 & 1 & & 7 \\
\hline 40 & & 1 & & & & 1 & & & & & & 2 \\
\hline 41 & & & & 2 & & 1 & & & & & & 3 \\
\hline 42 & & & 1 & & 4 & 1 & 1 & & & & & 7 \\
\hline 43 & & & & 11 & & 2 & & 2 & & & & 6 \\
\hline 44 & & & & 2 & 1 & & 1 & & 1 & & 1 & 6 \\
\hline 45 & & & & 1 & 1 & 2 & 2 & & 1 & & & 7 \\
\hline 46 & & & 2 & & & 1 & 1 & & 1 & & & 5 \\
\hline 47 & & 1 & & 1 & & 1 & & 1 & 1 & 1 & & 6 \\
\hline 48 & & & & & & 2 & & & & & & 2 \\
\hline 49 & & & & & & & 1 & & & & & 1 \\
\hline 計 & 1 & 2 & 6 & 35 & & 12 & 8 & 4 & 5 & 2 & 1 & 55 \\
\hline
\end{tabular}

$\mathrm{r}_{3} \pm \mathrm{Sr}_{3}=0.196 \pm 0.130$
第 71 表 兄弟間に扣ける第一大巨粜部 口蓋马隆長 $(\mathrm{mm})$ の相関

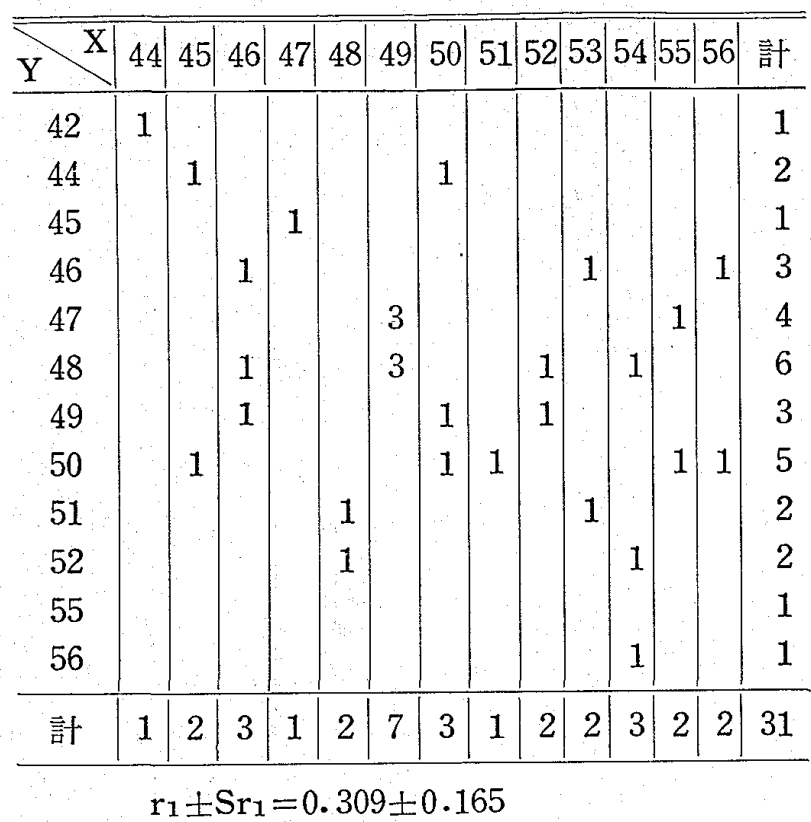

第 72 表 姉妹間に扔ける第一大自崡部 口蓋弓隆長 $(m \mathrm{~m} n)$ の相関

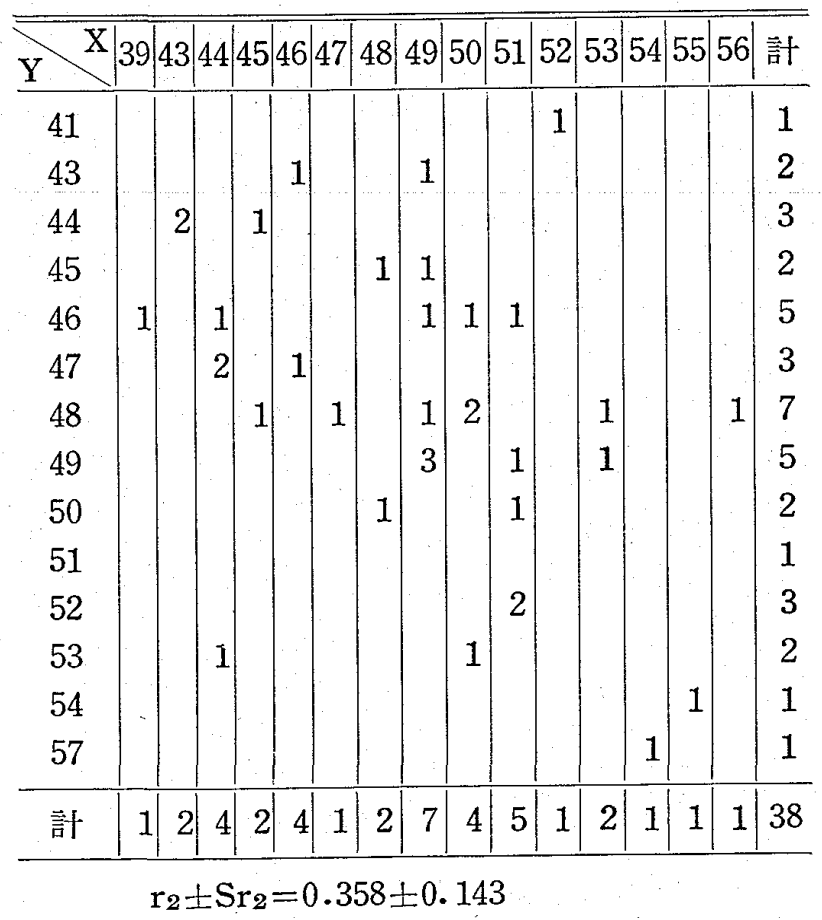


第 73 表 兄妹 (弟姉) 間に扣ける第一大曰 霜部口蓋弓隆長 $(\mathrm{mm})$ の相関

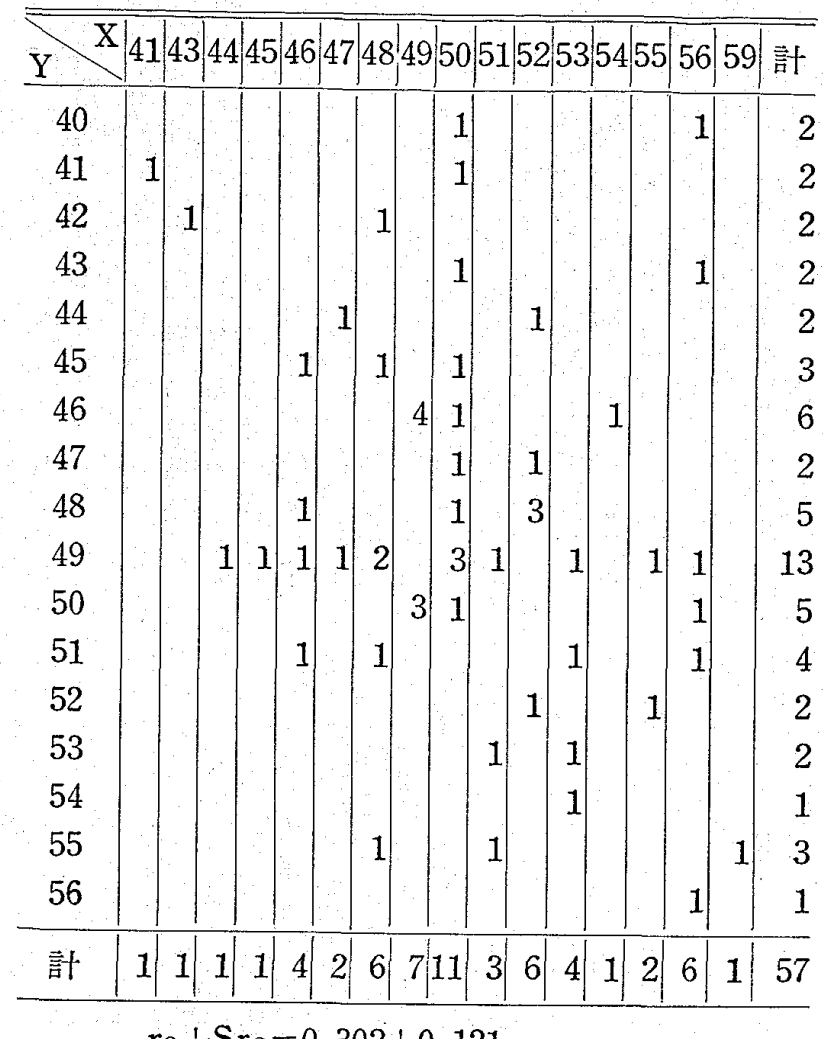

$\mathrm{r}_{3} \pm \mathrm{Sr}_{3}=0.302 \pm 0.121$

第 74 表 兄弟間に打ける正中縫合線の 長さ $(\mathrm{mm})$ の相関

\begin{tabular}{c|c|c|c|c|c|c|c|c|c|c|c|c|c}
\hline $\mathrm{X}$ & $\mathrm{X}$ & 26 & 27 & 28 & 30 & 31 & 32 & 33 & 34 & 35 & 36 & 37 & 計 \\
\hline 26 & & & & & & & & 1 & & & & 1 \\
28 & & & & 1 & & & 1 & & & & & 2 \\
30 & & & 1 & & & & 1 & & & & & 2 \\
31 & & & & & 1 & 1 & 1 & & 1 & & & 4 \\
32 & 1 & & & 1 & 1 & & & & & 1 & & 4 \\
33 & & 1 & & 3 & 1 & & & 1 & & 1 & & 7 \\
34 & & & & & 1 & & 1 & & & & 1 & 3 \\
35 & & & & & 1 & & & 2 & & 2 & & 5 \\
37 & & & & & & & & & & 1 & & 1 \\
38 & & & & & & & & & & 1 & & \\
\hline
\end{tabular}

$\mathrm{r}_{1} \pm \mathrm{Sr}_{1}=0.362 \pm 0.158$
第 75 表 姉妹間仗打ける正中縫合線の 長さ $(\mathrm{mm})$ の相関

\begin{tabular}{l|l|l|l|l|l|l|l|l|l|l|l}
\hline $\mathrm{X}$ & 27 & 29 & 30 & 31 & 32 & 33 & 34 & 35 & 36 & 37 & 計 \\
\hline 30 & & & & 1 & 2 & & 1 & & 1 & 1 & 6 \\
31 & & & 1 & 1 & & 1 & & & & & 3 \\
32 & 1 & & 1 & & 1 & 1 & 1 & 1 & & & 6 \\
33 & & & & 1 & 1 & 1 & & & & & 3 \\
34 & 1 & 1 & 2 & & & 1 & 1 & & 2 & & 8 \\
35 & & & 1 & & & 2 & 3 & & & 1 & 7 \\
36 & & & & & 2 & & & & & & 2 \\
37 & & & & & & 1 & & & & & 1 \\
38 & & & & 1 & & & & & & & 1 \\
39 & & & & 1 & & & & & & & 1 \\
\hline 計 & 2 & 1 & 5 & 5 & 6 & 7 & 6 & 1 & 3 & 2 & 38 \\
\hline \multicolumn{7}{c}{$\mathrm{r}_{2} \pm \mathrm{Sr} 2=-0.080 \pm 0.163$} & &
\end{tabular}

第 76 表 兄竦（弟姉）間に和ける正中縫 合線の長さ $(\mathrm{mm})$ の相関

\begin{tabular}{|c|c|c|c|c|c|c|c|c|c|c|c|c|c|c|}
\hline$Y X$ & $|26|$ & & 28 & & 30 & 31 & & $3 \mid 3$ & & 36 & $|37|$ & & & 計 \\
\hline 28 & & \multirow{10}{*}{1} & \multirow{10}{*}{1} & \multirow{10}{*}{\multicolumn{2}{|c|}{1}} & & \multirow{3}{*}{1} & & \multirow[b]{3}{*}{2} & \multirow{3}{*}{1} & \multirow{2}{*}{\multicolumn{2}{|c|}{1}} & & 1 \\
\hline 29 & & & & & & & & 1 & & & & & & 4 \\
\hline 30 & & & & & & & & & & & 1 & 1 & & 6 \\
\hline 31 & 1 & & & & & 1 & 3 & 12 & & 1 & 1 & & & 11 \\
\hline 32 & & & & & & & & 1 & 1 & & & & & 4 \\
\hline 33 & & & & & & & 1 &. & 1 & & 1 & 1 & 1 & 7 \\
\hline 34 & & & & & & 3 & 3 & 1 & 1 & 2 & & 1 & & 12 \\
\hline 35 & & & & & & & & 1 . & & & 1 & & & 6 \\
\hline 36 & & & & & & & & & & 1 & & 2 & & 3 \\
\hline 37 & & & & & & 1 & & 1 & & 1 & & & & 3 \\
\hline 計 & 1 & 1 & 1 & 1 & 3 & 6 & & 6 & 5 & 6 & 4 & 6 & 1 & 57 \\
\hline
\end{tabular}


-750 - (68) 同胞間と和ける歯冠幅（煩舌的）、蓋の大きさの相関

第 77 表

兄弟、姉妹及び兄妹 (弟姉) 間に和ける日蓋司隆長の相関係数

\begin{tabular}{|c|c|c|c|c|c|c|}
\hline \multirow{2}{*}{ 項 } & \multicolumn{2}{|c|}{ 男：男 } & \multicolumn{2}{|c|}{ 女: 女 } & \multicolumn{2}{|c|}{ 男：女 } \\
\hline & $\mathrm{N}_{1}$ & $\mathrm{r}_{1} \pm \mathrm{Sr}_{1}$ & $\mathrm{Ne}$ & $\mathrm{r}_{2} \pm \mathrm{Sr}_{2}$ & $\mathrm{~N}_{3}$ & $\mathrm{r}_{3} \pm \mathrm{Sr} 3$ \\
\hline 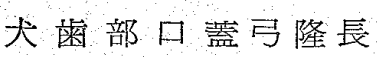 & 30 & $0.406 \pm 0.154$ & 37 & $0.331 \pm 0.148$ & 57 & $0.221 \pm 0.127$ \\
\hline 第一小臼歯部口譩马隆長 & 30 & $0.348 \pm 0.163$ & 39 & $0.304 \pm 0.147$ & 55 & $0.280 \pm 0.125$ \\
\hline 第二小心橉部口蒀马隆長 & 31 & $0.293 \pm 0.166$ & 38 & $0.220 \pm 0.156$ & 55 & $0.196 \pm 0.130$ \\
\hline 第一大日電部门䕊当隆長 & 31 & $0.309 \pm 0.165$ & 38 & $0.358 \pm 0.143$ & 57 & $0.302 \pm 0.121$ \\
\hline 口蓋正中綘合線の長さ & 31 & $0.362 \pm 0.158$ & 38 & $-0.080 \pm 0.163$ & 57 & $0.082 \pm 0.132$ \\
\hline
\end{tabular}

各組合せ内の相関係数は兄弟方 $0.293 \sim 0.406$ 、姉

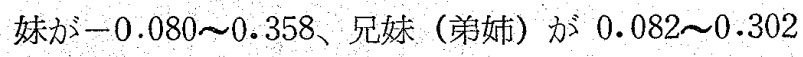
である。

a. 兄弟乙姉妹の上較
第78表のと扣りで、两組合せ間の相関係数の差は、 級別及び全般的 $\left(\mathrm{Mr} / \mathrm{S}_{\mathrm{Mr}}=1.038\right)$ 飞を有意義性力 ないが、兄弟に和ける相関性が姉妹のそれよりわずか に大である。
第 78 表

\begin{tabular}{|c|c|c|c|c|c|c|}
\hline & \multicolumn{2}{|c|}{ 男：男一女：女 } & \multicolumn{2}{|c|}{ 男：男一男：女 } & \multicolumn{2}{|c|}{ 女：女一男：女 } \\
\hline & $\mathrm{d}_{1} \pm \mathrm{Sd}_{1}$ & $\mathrm{~d} / \mathrm{Sd}$ & $\mathrm{d}_{2} \pm \mathrm{Sd}_{2}$ & $\mathrm{~d} / \mathrm{Sd}$ & $\mathrm{d}_{3} \pm \mathrm{Sd}_{3}$ & $\mathrm{~d} / \mathrm{Sd}$ \\
\hline 犬歯部口蓋弓隆長 & $0.752 \pm 0.214$ & 0.350 & $0.185 \pm 0.199$ & 0.929 & $0.110 \pm 0.195$ & 0.564 \\
\hline 第一小曰歯部口臸弓隆長 & $0.044 \pm 0.219$ & 0.200 & $0.068 \pm 0.205$ & 0.331 & $0.024 \pm 0.193$ & 0.214 \\
\hline 第二小曰画部口蓄亏隆長 & $0.073 \pm 0.227$ & 0.321 & $0.097 \pm 0.210$ & 0.461 & $0.024 \pm 0.203$ & 0.118 \\
\hline 第一大日電部口臸弓隆長 & $-0.049 \pm 0.218$ & -0.224 & $0.007 \pm 0.204$ & 0.034 & $0.056 \pm 0.187$ & 0.299 \\
\hline 日蹎正中綘合線の長さ & $0.442 \pm 0.227$ & 1.947 & $0.280 \pm 0.206$ & 1.359 & $-0.162 \pm 0.209$ & -0.775 \\
\hline $\begin{array}{l}\mathrm{K}=5 \\
\mathrm{~S}_{\mathrm{Mr}}=0.500\end{array}$ & \multicolumn{2}{|c|}{$\begin{array}{l}\mathrm{Mr}=0.519 \\
\mathrm{Mr} / \mathrm{S}_{\mathrm{Mr}}=1.038\end{array}$} & \multicolumn{2}{|c|}{$\begin{array}{l}\mathrm{Mr} \quad=0.623 \\
\mathrm{Mr} / \mathrm{S}_{\mathrm{Mr}}=1.246\end{array}$} & \multicolumn{2}{|c|}{$\begin{array}{l}\mathrm{Mr} \quad=0.066 \\
\mathrm{Mr} / \mathrm{S}_{\mathrm{Mr}}=0.132\end{array}$} \\
\hline
\end{tabular}

b. 元弟乙见妹（弟姉）の比較

第78表のよj.飞、級別、全般的 $\left(\mathrm{Mr} / \mathrm{S}_{\mathrm{Mr}}=1.246\right)$ にも有意意性の差かふないが、相関性は姉妹の方がわず かに大である。

c. 姉妹と兄妹 (总妏) の比較

第78表のよう飞、級別、全般的 $\left(\mathrm{Mr} / \mathrm{S}_{\mathrm{Mr}}=0.132\right)$ にも有意義性の差はない。両組合せの相関性の差はほ とんどない。

\section{d. 小 括}

兄弟、姉妹及び兄妹（弟姉）の口盖隆長及び口琵 正中縫合線の長さの相関性は、各組合せ間に有意義性 の差はないが、兄弟文もつとも大きく、ついで姉妹、 兄妹 (弟姉)である。姉妹と兄妹（弟姉）との相関性
の差はほとんどない。

\section{$\mathrm{V}$ 口蓋 幅}

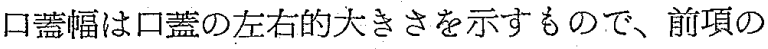
口蓋弓隆長の測計点の左右両端間の直線距䧺である。 口壒幅は䨑列弓幅ににているが、歯列局幅は歯列弓の 左右的大きさを示し、歯の配列状堨てよって多少異な ってくる。口瓂幅も曾の配列状態によって影響される が、菌列幅よりもそれは小である。口蓋幅犬画部、 第一小曰歯部、第二小曰歯部及び第一大曰歯部であ る。

\section{1. 男と女の口蓋幅の比較}

男女間の口蓋幅を比べると第79表のと祸りである。 
第 79 表 男と女の平均口蓋幅の比較

$(\mathrm{mm})$

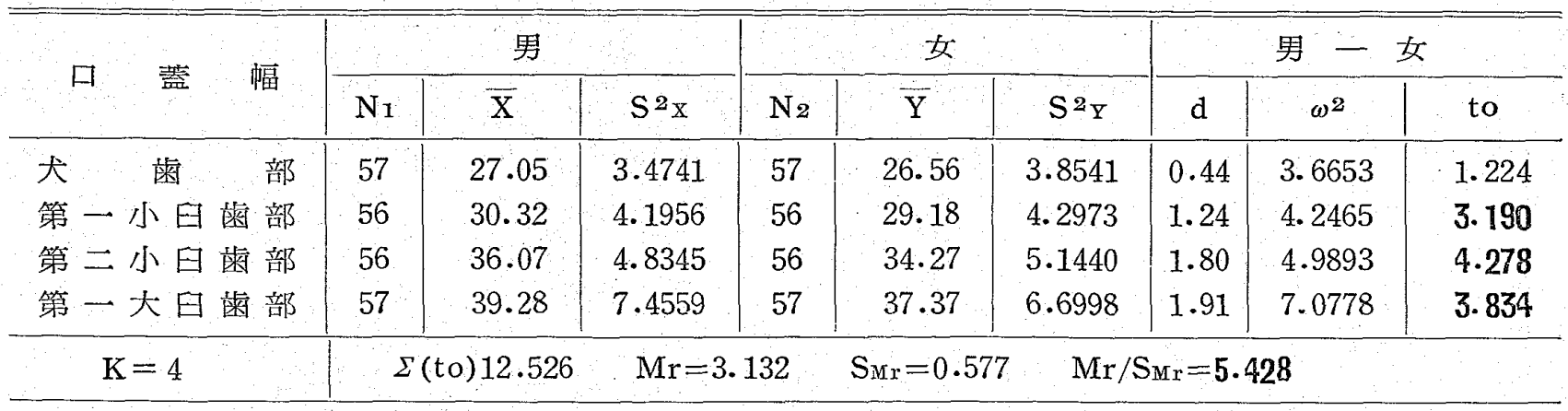

男女間の差有意義性のある口蒀幅は、犬菡部を除 いた第一小歯部、第二小臼電部及び第一大曰菌部 で、いずれも男が女よりも大である。全般的に男女間 の差を比べると、 $\mathrm{Mr} / \mathrm{S}_{\mathrm{Mr}}$ が 5.428 で有意義性の差が あり、男が好り大である。

第 80 表 兄弟間に扣ける犬葴部口蓋幅 $(\mathrm{mm})$ の相関

\begin{tabular}{c|c|c|c|c|c|c}
\hline $\mathrm{Y} \mathrm{X}$ & 24 & 26 & 27 & 28 & 29 & 計 \\
\hline 24 & 1 & & & & & 1 \\
25 & & 2 & 1 & 1 & & 4 \\
26 & 1 & 3 & 2 & & & 6 \\
27 & & 2 & 4 & & & 6 \\
28 & 1 & 2 & 1 & & 1 & 5 \\
29 & & & & 1 & 1 & 2 \\
30 & & & 2 & 1 & 1 & 4 \\
32 & & & & 1 & & 1 \\
35 & & & & 1 & & 1 \\
\hline 計 & 3 & 9 & 10 & 5 & 3 & 30 \\
\hline
\end{tabular}

$\mathrm{r}_{1} \pm \mathrm{Sr}_{1}=0.481 \pm 0.142$

第 81 表 姉族間に和ける犬崡部口瓂幅 $(\mathrm{mm})$ の相関

\begin{tabular}{c|c|c|c|c|c|c|c|c|c|c|c}
\hline \hline $\mathrm{X}$ & 22 & 23 & 24 & 25 & 26 & 27 & 28 & 29 & 30 & 計 \\
\hline 22 & & 1 & & & & & & & & 1 \\
24 & & 1 & 3 & 1 & & & & & & 5 \\
25 & & 1 & 1 & 1 & & 2 & & & & 5 \\
26 & & & & 2 & 2 & 1 & 1 & 1 & 1 & 8 \\
27 & 1 & & & 3 & 1 & 1 & 1 & 2 & & 9 \\
28 & & & 1 & 1 & 2 & 1 & 1 & & & 6 \\
29 & & & & & & 1 & 2 & & & 3 \\
\hline 詰 & 1 & 3 & 5 & 8 & 5 & 6 & 5 & 3 & 1 & 37 \\
\hline
\end{tabular}

$\mathrm{r}_{2} \pm \mathrm{Sr}_{2}=0.475 \pm 0.129$

\section{2. 同胞間における口蓋幅の相関係数}

兄弟、姉妹及び兄妹（弟姉）の各組合せ内の口琴幅 の相関表及び相関流数は、第80 92表のと扔りであ る。

第 82 表兄妹（弟姉）間に扔ける犬雪部 口蓋幅 $(\mathrm{mm})$ の相関

\begin{tabular}{c|r|r|r|r|r|r|r|r|r|r|r}
\hline $\mathrm{X}$ & 24 & 25 & 26 & 27 & 28 & 29 & 30 & 31 & 33 & 計 \\
\hline 23 & & 2 & 1 & & & & & & & 3 \\
24 & & 2 & & & 1 & 1 & & & & 4 \\
25 & 3 & 2 & 1 & 4 & 1 & 1 & & & & 12 \\
26 & & 2 & 1 & 2 & 1 & 3 & 2 & & 1 & 12 \\
27 & & & & 2 & 2 & 2 & 1 & & & 7 \\
28 & & 2 & 2 & 2 & 2 & & & 1 & & 9 \\
29 & & 2 & & 3 & & 1 & & & & 6 \\
30 & & 1 & & 1 & & & & & & 2 \\
31 & & & & 1 & & 1 & & & & 2 \\
\hline 計 & 3 & 13 & 5 & 15 & 7 & 9 & 3 & 1 & 1 & 57 \\
\hline \multicolumn{6}{c}{$\mathrm{r}_{8} \pm \mathrm{Sr}$} \\
\hline
\end{tabular}

第 83 表 兄弟間に捛ける第一小曰歯部口 蓋幅 $(\mathrm{mm})$ の相関

\begin{tabular}{c|c|c|c|c|c|c|c|c|c|c|c|c}
\hline \hline $\mathrm{Y}$ & $\mathrm{X}$ & 24 & 25 & 27 & 28 & 29 & 30 & 31 & 32 & 33 & 34 & 計 \\
\hline 25 & 1 & & & & & & & & & & 1 \\
27 & & 1 & & 1 & & & & & & & 2 \\
28 & & & & & 2 & & 2 & & & & 4 \\
29 & & & & & & 2 & & 1 & & & 3 \\
30 & & & 1 & & & 1 & & & & & 2 \\
31 & & & & 1 & & 2 & 1 & 1 & 1 & & 6 \\
32 & & & & 1 & 1 & 2 & 2 & 1 & & & 7 \\
33 & & & & 1 & & & & 1 & 1 & 1 & 4 \\
34 & & & & & & & 1 & & & & 1 \\
\hline 訂 & 1 & 1 & 1 & 4 & 3 & 7 & 6 & 4 & 2 & 1 & 30 \\
\hline
\end{tabular}

$r_{1} \pm S r_{1}=0.625 \pm 0.113$ 
第 84 表 姉妹間に扣ける第一小曰荬部口 蓋幅 $(\mathrm{mm})$ の相関

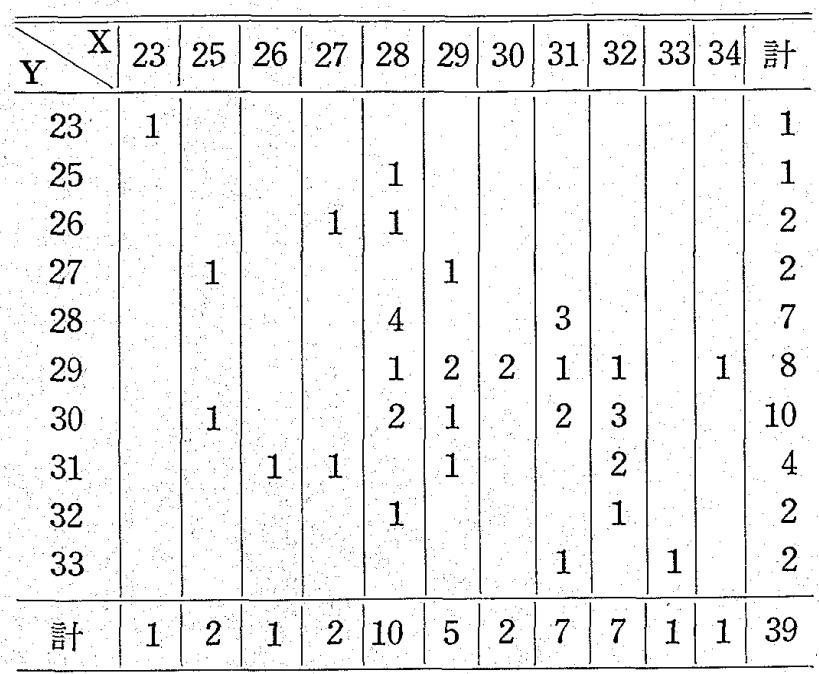

$\mathrm{r}_{2} \pm \mathrm{Sr}_{2}=0.497 \pm 0.122$

第 85 表 兄妹（弟姉）間に扣ける第一小

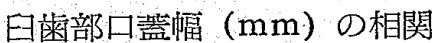

\begin{tabular}{c|r|r|r|r|r|r|r|r|r|r|r}
\hline $\mathrm{X}$ & 25 & 27 & 28 & 29 & 30 & 31 & 32 & 33 & 34 & 36 & 計 \\
\hline 25 & & & & 1 & & 1 & & & & & 2 \\
26 & & & 1 & 1 & & & & & & & 2 \\
27 & 1 & & 1 & 2 & 1 & 3 & & & 1 & & 9 \\
28 & & 1 & 1 & 3 & & 2 & 2 & & & & 9 \\
29 & & & 2 & 2 & & 2 & 2 & & & & 10 \\
30 & & & & 2 & & 2 & 3 & 1 & 1 & & 9 \\
31 & & & 2 & 2 & 2 & 1 & & 1 & & 1 & 9 \\
32 & & 1 & & & 1 & & 2 & & 1 & & 3 \\
33 & & & & & & & 1 & 1 & & & 2 \\
36 & & & 1 & & & & & & & & 1 \\
\hline Y & 1 & 2 & 8 & 13 & 4 & 11 & 10 & 3 & 3 & 1 & 56 \\
\hline
\end{tabular}

$\mathrm{r}_{3} \pm \mathrm{Sr}_{3}=0.209 \pm 0.128$
第 86 表 兄弟間仗捛ける第二小曰歯口 蓋幅 $(\mathrm{mm})$ の相関

\begin{tabular}{l|l|l|l|l|l|l|l|l|l|l|l}
\hline $\mathrm{Y}$ & $\mathrm{X}$ & 32 & 33 & 34 & 35 & 36 & 37 & 38 & 39 & 40 & 計 \\
\hline 31 & & & & 1 & 1 & & & & & 2 \\
33 & & 1 & & & & & & & & 1 \\
34 & & & 3 & 1 & 1 & 2 & & & & 7 \\
35 & 1 & 1 & & 2 & & & & & & 4 \\
36 & & 1 & & & 1 & 1 & 1 & & & 4 \\
37 & & & 1 & & 1 & 1 & & 1 & & 4 \\
38 & & & & 1 & 2 & & 2 & & 1 & 6 \\
39 & & & & 1 & & & & 1 & 1 & 3 \\
\hline 謓 & 1 & 3 & 4 & 6 & 6 & 4 & 3 & 2 & 2 & 31 \\
\hline
\end{tabular}

第 87 表 姉妹間に扣ける第二小手歯部口 蓋幅 $(\mathrm{mm})$ の相関

\begin{tabular}{c|c|c|c|c|c|c|c|c|c|c|c|c|c}
\hline \hline $\mathrm{X}$ & 29 & 30 & 31 & 32 & 33 & 34 & 35 & 36 & 37 & 38 & 39 & 計 \\
\hline 30 & & & & & 1 & & & & 1 & & & 2 \\
31 & & & & & & & 2 & & & & & 2 \\
32 & 1 & & & & & 1 & & & & & & 2 \\
33 & & & & & 1 & 2 & & 1 & & & & 4 \\
34 & & 1 & & 1 & 1 & 2 & 1 & 1 & & & 1 & 8 \\
35 & & & 1 & & 1 & & 3 & 1 & & & & 6 \\
36 & & & & & 1 & 1 & & 1 & 2 & 3 & & 8 \\
37 & & & & & & 1 & & & & & 1 & 2 \\
39 & & & & & & & & & & 2 & 1 & 3 \\
40 & & & & & & & & & & \\
\hline
\end{tabular}

$\mathrm{r}_{2} \pm \mathrm{Sr}_{2}=0.666 \pm 0.091$ 
第 88 表 兄妹間に扑ける第二小曰函部口 蓋幅 $(\mathrm{mm})$ の相関

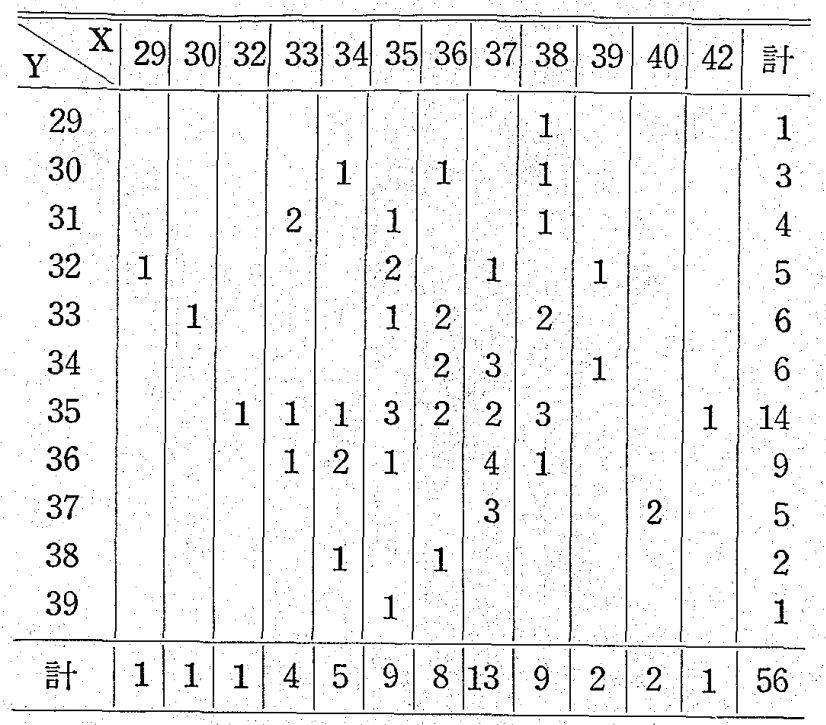

$\mathrm{r}_{3} \pm \mathrm{Sr}_{3}=0.112 \pm 0.133$

第 89 表 兄弟間に打ける第一大四䨑部口 蓋幅 $(\mathrm{mm})$ の相関

\begin{tabular}{|c|c|c|c|c|c|c|c|c|c|c|}
\hline $\mathrm{Y} X$ & 33 & 37 & 38 & 39 & 40 & 41 & 42 & 43 & 44 & 計 \\
\hline 36 & & & & 1 & & 1 & & & & 2 \\
\hline 37 & & 3 & 1 & & 1 & & & & & 5 \\
\hline 38 & 1 & & 2 & 2 & 2 & & & & & 7 \\
\hline 39 & & 1 & & 1 & & & 1 & 2 & & 5 \\
\hline 40 & & & & 4 & 1 & & 1 & & & 6 \\
\hline 41 & & & 1 & & 1 & 1 & & & & 3 \\
\hline 42 & & & & 1 & & & & & & 1 \\
\hline 43 & & & & & & & & & 1 & 1 \\
\hline 44 & & & & & 1 & & & & & 1 \\
\hline 計 & 1 & 4 & 4 & 9 & 6 & 2 & 2 & 2 & 1 & 31 \\
\hline
\end{tabular}

第 90 表 姉妹間に初ける第一大曰歯部口 䓝幅 $(\mathrm{mm})$ の相関

\begin{tabular}{|c|c|c|c|c|c|c|c|c|c|c|c|c|c|}
\hline $\mathrm{Y} X$ & 32 & 34 & 35 & 36 & 37 & 38 & 39 & 40 & 41 & 42 & 43 & 46 & 計 \\
\hline 32 & & & & & & & 2 & & & & & & 2 \\
\hline 33 & & 1 & 1 & & & & & & & & & & 2 \\
\hline 34 & & & & & & 1 & & & & & & & 1 \\
\hline 35 & 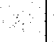 & & & 1 & & & & & & & & & 1 \\
\hline 36 & 1 & & 1 & 2 & & 2 & 3 & & & & & & 9 \\
\hline 37 & & & 2 & & 3 & 1 & & $\because$ & & 1 & & & 7 \\
\hline 38 & & & & 2 & 1 & 1 & & & & 1 & & & 5 \\
\hline 39 & & & & & & 1 & 2 & & & & & & 3 \\
\hline 40 & & & & & & 1 & 1 & 1 & 2 & & & 1 & 6 \\
\hline 42 & & & & & & & & & & & 1 & & 1 \\
\hline 43 & & & $\because$ & & & & & & & 1 & & & 1 \\
\hline 計 & 1 & 1 & 4 & 5 & 4 & 7 & 8 & 1 & 2 & 3 & 1 & 1 & 38 \\
\hline
\end{tabular}

第 91 表 兄妹間に扔ける第一小曰䨑部口 蓋幅 $(\mathrm{mm})$ の相関

\begin{tabular}{|c|c|c|c|c|c|c|c|c|c|c|c|c|c|c|}
\hline$Y$ & $\mid 32$ & 34 & 35 & 36 & 37 & 38 & 39 & $40 \mid$ & $|41|$ & 42 & 43 & 44 & 45 & 計 \\
\hline 31 & & & & & & & & & 1 & & & & & 1 \\
\hline 32 & & & & 1 & & & 1 & & & & & & & 2 \\
\hline 33 & & & & & & & 1 & & & & & & & 1 \\
\hline 34 & 1 & & 1 & & & & & & & 2 & & & & 4 \\
\hline 35 & & & & & 1 & & & & 1 & & & & & 2 \\
\hline 36 & & 1 & & & & 1 & 4 & 2 & & & & & & 8 \\
\hline 37 & & & & 1 & 1 & 1 & 2 & 3 & & & & & 1 & 9 \\
\hline 38 & & & & 1 & . & & 3 & 5 & & 1 & 1 & & & 11 \\
\hline 39 & & & 2 & 1 & 1 & 1 & 1 & & 1 & & 2 & & 1 & 10 \\
\hline 40 & & & & & & 2 & & 1 & & & 1 & & & 4 \\
\hline 41 & & & & & & & & & & & & 1 & 1 & 2 \\
\hline 42 & & & & & & & & 2 & & & & & & 2 \\
\hline 43 & & & & 1 & & & & & & & & & & 1 \\
\hline 計 & 1 & 1 & 3 & 5 & 3 & 5 & 12 & 13 & 3 & 3 & 4 & 1 & 3 & 57 \\
\hline
\end{tabular}

$\mathrm{r}_{3} \pm \mathrm{Sr}_{3}=0.187 \pm 0.129$ 


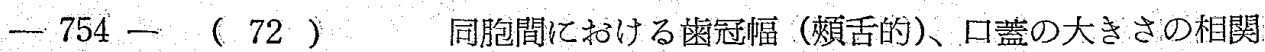

第 92 表

兄弟、姉妹及び见妹（弟姉）間に扣ける口蓋幅の相関係数

\begin{tabular}{|c|c|c|c|c|c|c|c|c|}
\hline \multirow{2}{*}{$\square$} & \multirow{2}{*}{ 蓋 } & \multirow{2}{*}{ 幅 } & \multicolumn{2}{|c|}{ 男：男 } & \multicolumn{2}{|c|}{ 女：女 } & \multicolumn{2}{|c|}{ 男：女 } \\
\hline & & & $N_{1}$ & $\mathrm{r} \pm \mathrm{Sr}$ & $\mathrm{N}_{2}$ & $\mathrm{r}_{2} \pm \mathrm{Sr}_{2}$ & N. & $\mathrm{r} 3 \pm \mathrm{Sr}_{\mathrm{s}}$ \\
\hline 犬 & 歯 & 部 & 30 & $0.481 \pm 0.142$ & 37 & $0.475 \pm 0.129$ & 57 & $0.152 \pm 0.130$ \\
\hline & 小曰䨑 & 部 & 30 & $0.625 \pm 0.113$ & 39 & $0.497 \pm 0.122$ & 56 & $0.209 \pm 0.128$ \\
\hline 第 & 小曰藏 & 部 & 31 & $0.462 \pm 0.143$ & 38 & $0.666 \pm 0.091$ & 56 & $0.112 \pm 0.133$ \\
\hline 第 & 大日歯 & 部 & 31 & $0.657 \pm 0.104$ & 38 & $0.512 \pm 0.121$ & 57 & $0.187 \pm 0.129$ \\
\hline
\end{tabular}

口蓋幅の相関係数は、兄弟が $0.462 \sim 0.657$ 、姉妹か

$0.475 \sim 0.666$ 、兄妹（弟姉）は0.112〜0.209である。

a. 兄弟と姉妹の比較
第93表のように、級別及び全般的 $\left(\mathrm{Mr} / \mathrm{S}_{\mathrm{Mr}}=0.220\right)$ 亿も有意義性の差方ない。兄弟と姉妹との口䓝幅の相 関性の差はほとんどない。

第 93 衰

兄第、姉妹及び兄妹（弟效）間に和ける口荎幅の相関係数の比較

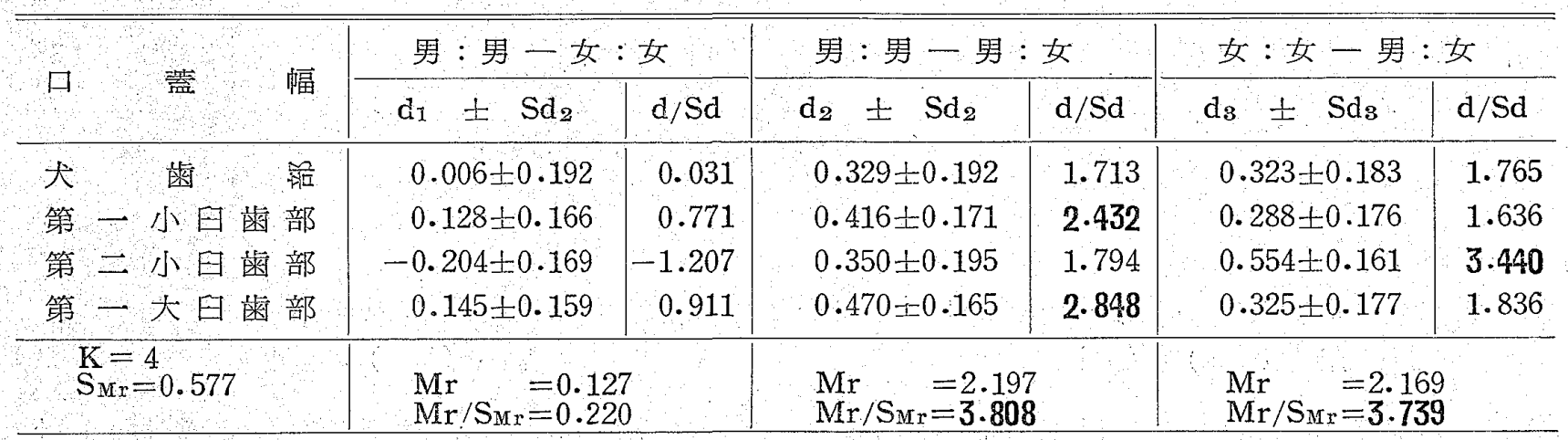

b。兄弟と兄哮（弟姉）の比教

第93表のように、兄弟と兄妹（弟峬）の相関係数の

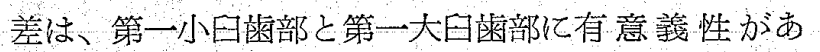
b。兄弟の相関性肪大である。全般的に兄弟と兄妹 (牙姉) $の$ 差を比べる、Mr/S Mr が 3.808 で有意義

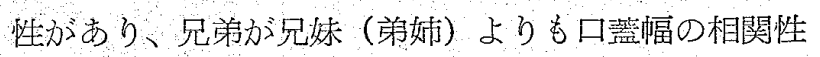
ぬ大である。

c. 姉陡と兄枺（弟姉）の比䩙

第93表のように、級別に差の有意義性のあるもの は、第二小曰蒾部げけで、姉味の方が相関性は大であ る。全般的と両組合せ間の相関係数の差を比べると、
$\mathrm{Mr} / \mathrm{S}_{\mathrm{Mr}}$ が 3.759 で有意義性の差怔あり、姉姝の相関 性が大である。

\section{d.小括}

兄总、姉妹及び兄妹（弟姉）の口蓋幅の相関性はき わめて大きく、兄愵と姉妹間の相関性の差はほとんど ないが、兄炼（弟姉）のそれよりも大である。

\section{3. 口蓋と口蓋弓隆長との相関}

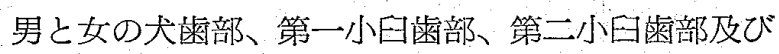
第一大巨崡部の口謤幅と口蓋口隆長との相関係数を比 ベると、第94表のと福りである。
第 94 表

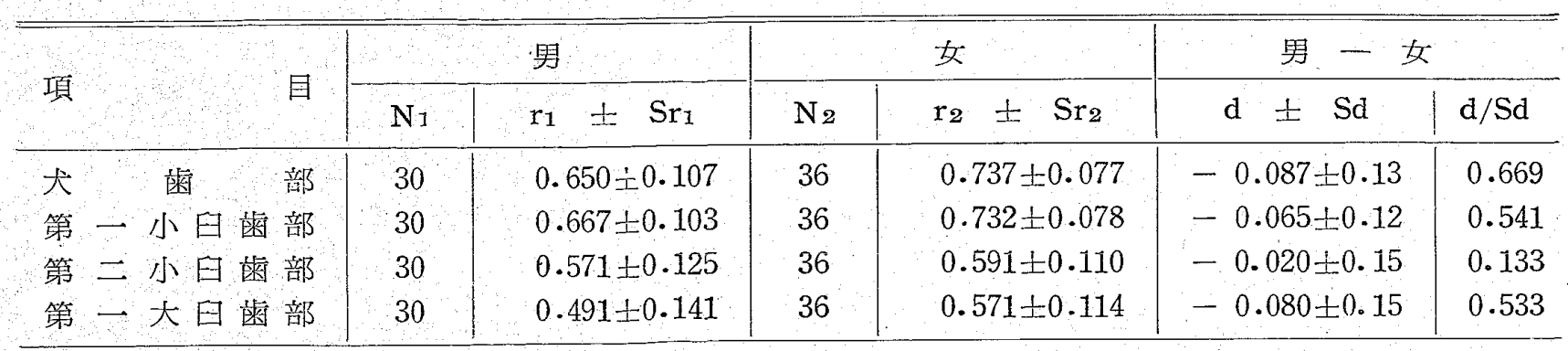


口蓋幅と口营引隆長との相関係数は、男力 0.491〜 0.667 、女は 0.571 〜 0.737 、男女とも相関性はきわ めて大である。男と女の相関係数を比へるる、各項目 とも有意義性の差方ない。男女間の相関性の差はほと んどない。

\section{総 括 と考 按}

徉来、人類遗伝学の研究は戦後急速な進步を示し、 数多くの報告があ。しかし、日腔領域の諸形暨につ いての遺伝学的研究は、歯学の他の研究に比べて著し く少ない。ととに異常形䫓の賛伝学的研案は、きわめ て少ない。

口腔の諸形質の顀伝学的研究は、数窒の荷宮 $6 \sim 10)$ 並 びに教室研究生門脇 ${ }^{11)}$ 、宮島12)，阿南13)、富U14)、門 本15)、津島 ${ }^{16)}$ 、作間22) などか溌表を行なつた。荷宫 6〜10)の口腔諸形斦の遺伝研究は、血族結媳による祝島 島民について㐘科衛生学的研究を行ない、歯列局形態

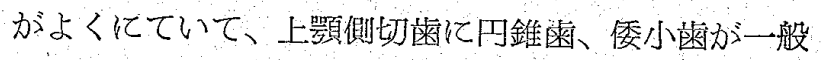
他の地方民のそれより多く几九州、中国地方人につい て円錐疄、倯小粎は劣性遺伝することを指摘した。双 生児てついて、身長、体重、胸囲、頡、顔、日、咬

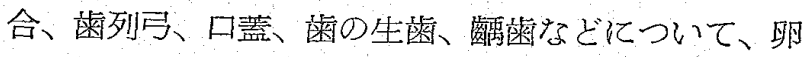
性間のてれらの諸形質の類似性、諸形質に対する遺伝 的影響と環境的影響を報告した。つぎに䍃子間すなわ ち、父と息子、父と旅、母と息子、母と娘閒に好り 日腔諸形質の類似性を平均百分率により比較し、宗た 各組合せ内の相関係数放ら：諸形質に対する各組合せ 別の遺伝と環境の影響营報告している。門脇11) は同胞 間おける咬合と崡列引について、同性と異性との組合 甘間の類似性を平均百分率によって研究した。阿南13) は双生呪、同胞及び親子に扔ける近遠心的菡冠幅の相

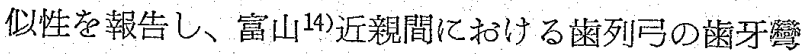
曲について類似性学発表した。門本15) は口踢度と咬

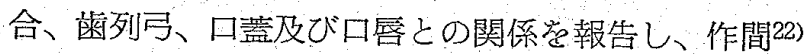
は同胞、漞子間に和いて窗冠傾斜度、宮島12)は近親間 に扣いて雨牙揄転の相関性などの研究を発表してい る。

これらの遺任研究のうち、私の行なつた項目につい ての報告はなく、成績の比較は困難である。私の研究

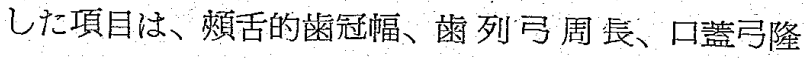
長、口监正中縫合線の長さ及び口盖幅で、同胞の性組 合せ、すなわち、兄弟、姉炼、兄姝 (弟姉) の組合せ 内の測計項目の相関詼をみるために、相関係数を出 し、各性組合せ間の相関性定比較して。
歯冠幅については、阿南13)

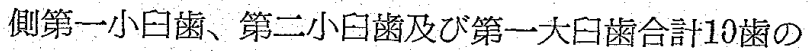

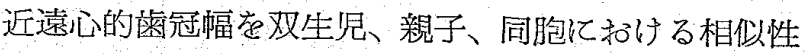
を報告している。私は上、下顎左側 7菡について煩舌 的㧘冠幅を同胞の性組合过内の相関係数出し、相関 性を比較したので、阿南13)の成續と比較は困難であ る。阿南 ${ }^{13)}$ の成績によると、上顎右側大虍加ら左側第

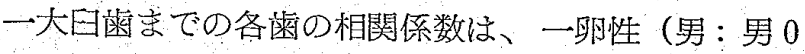
.9 0.7、女: 女 $0.9 \sim-0.1$ )、同性二卵性（男：男 0 $.8 \sim 0.2$ 、女: 女 $0.7 \sim 0.3$ )、異性二卵性は $0.7 \sim 0.01$ で、がいて相関性は一卵性がもっとも大きく、同性

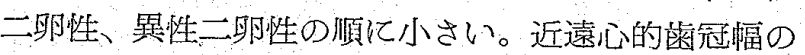
相関性はきわめて大である。

著者の同胞間上、下㖽 (左側) 各 7 菡の頉舌的齿冠 幅の相関性注双生児の近遠心的歯冠幅のそれよりも小 さい。阿南13) の親子の相関係数は、父：息子 $0.35 \sim$ 0.05、父: 娘は0.4〜0.05、寻と息子では0.5〜0.04、 母: 娘は0.5〜 (-0.2) で性組合せの粺子間では性組 合せ間の相関性は差がほとんどない。同胞間では、兄

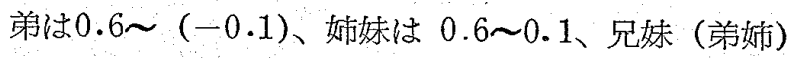
は 0.7〜 (-0.04) で性組合せ間では差がほとんどな い。同胞閒に扣ける蒾冠幅の相関性は、近遠心的崡冠 幅か瀬舌的歯冠幅よりも大である。

䊝列弓周長についての瀢伝的研究は私の報告だけで 他と比較できないか、雪列弓周長の相関係数は、上顎

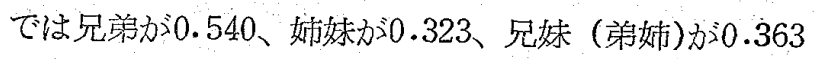
で各組合せ間の相関性の有意義差はないが、完弟がも っとも大きく、姉炼と完妹（弟姉）との差はほとんど ない。下顎雨列甹周長の相関係数は、兄弟が 0.411 、 姉妹は0.753、兄妹（弟姉）は0.180で相関性は姉姝が もっとも大きく、ついで兄牙、兄妹（涕姉）の順に小

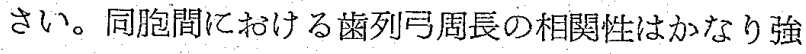
く、私の計測項目のなかでもっとも大である。

日蓋弓隆長の遣伝について虫、他に報告がなく、比 較できない。同胞間の相関係数は、兄弟が 0.406 0.293 、姉妹は $0.358 \sim(-0.08)$ 、兄菽（弟姉）は $0.280 \sim 0.082 て ゙$ 汃らの相関性があり、各性䋎合甘間 の差哇ほとんどない。

口笽正中縫合線の長さについての遗伝研究は他にな

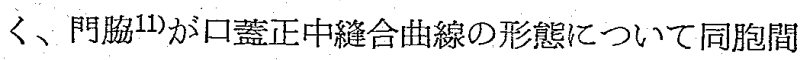
の類似性は兄弟、姉姣の類似性が兄妹（弟姉）よりも 大であると述べている。本研究では口蓋正宋縫合線の 長さの相関係数は、兄弟が $0.362 、$ 姉妹がー0.080、兄

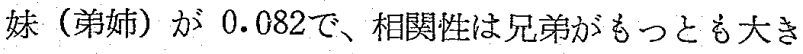


く、姉妹と兄妹（弟姉）との差はほとんどない。 口荎幅についての研究は川几22) が年令的発育の研究 があるだけで、遺伝研究はない。口監幅にやや類似し た荬列马幅てついて門脇 ${ }^{11)}$ は、同胞間の類似性は兄弟 が姉妹よりやや類似し、同性組合せは異性組合せより もまさっていると述へている。私の成綨は同胞の相関 係数は、兄弟方 $0.657 \sim 0.481$ 、坁妹标 $0.666 \sim 0.475$ 、 兄妹 (弟姉) は0.209 0.112である。口蓋幅の相関性 は兄弟、姉妹間の差はほとんどないが、兄妹（弟姉） より大である。口蓋愊の同胞間の相関性は強い。

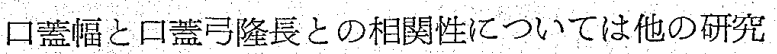
成績かなく、男女の相関係数柱、男か0 0.667〜0.491、 女は0.737〜0.571で男女間の相関性の差はないが、男 女とも相関性はきわめて大である。

\section{む す び}

従来、口腔諸形質の遺伝学的研究には、いまだ頓舌

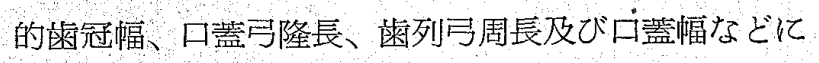
ついての遺伝学的研究は行われていないようである。 私はてれらの正常な諸形質の遺伝学的研究を行なうこ とは、歯学上きわめて有意義性のあるように思い、本 研究を行なった。

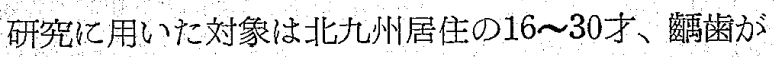
あって測計困難なものは省き、兄弟 38 組、姉妹 40 組、 兄妹 (弟姊) 59組、合計137組、274名である。乙れら の口腔印象石旁模型を作り、模型上に扣いて測計を行 なった。

観測項目と観測方法

頓舌的歯冠幅：上、下影左側の知菌を除いいた14

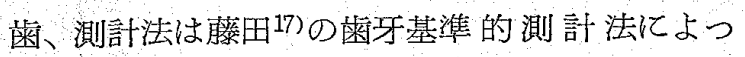
to

雪列弓周長：上、下顎の左右両側第一大日齿の近 心槙側咬頭頂間の崡列弓の外周の長さ。

口蓋幅：犬眔部、第一小臼崡部、第二小曰歯部及 び第一大曰歯部の口蓋側の歯肉縁の中央間の距離 老測計した。

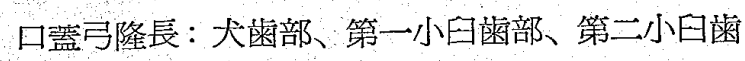
部及び第一大曰歯部測計した。口蓋弓隆長は口蓋 幅を測計した上顎左右両側犬雪、第一小曰畨、第 二小曰齒及び第一大曰歯の測計点間を口蓋粘膜上 そ印記し、ての線とそうてヒユーズを圧接し、と れを直線にして測計した。口蓋幅は口蓋の左右的 大きさを示し、口蓋亏隆長は口蓋弓隆の大きさを 示すものである。
口蓋正中縫合線の長さ：口蓋正中 縫 合 線にそう て、前方は左右雨側中切歯間の口蓋側菌間孚頭、 後方は第一大雬部口蓋亏隆長の線と口蓋正中咬 合線とまじわる点を测訂点とした。

各項目の観測值汃引、全資料の男と女の平均值と観 測値の分散を出した。各項目について男女間の差を比 べた。差の判定には、級別には $\mathrm{t}$ 一検定を行ない、観 測項目の各群每に平均比によって判定した。

つぎ観測項目について、同胞の性組合せ、すなわ ち、兄弟、姉妹及び兄妹（弟姉）の各組合せ内に扔け る相関係数とその標準编差を出した。性組合せ間の相 関係数の差の判定は、級別には二つの相関係数と差の 標準偏差によって判定した。観測項目の各群每けは平 均比々よって判定した。

結果はつぎのようである。

\section{1. 顂舌的菻冠幅}

男と女の上、下顎の左側中切曾、側切囦、犬雪、第 一小曰菡、第二小曰歯、第一大曰歯及び第二大臼歯の 平均頓舌歯冠幅は、つざの表のようである。

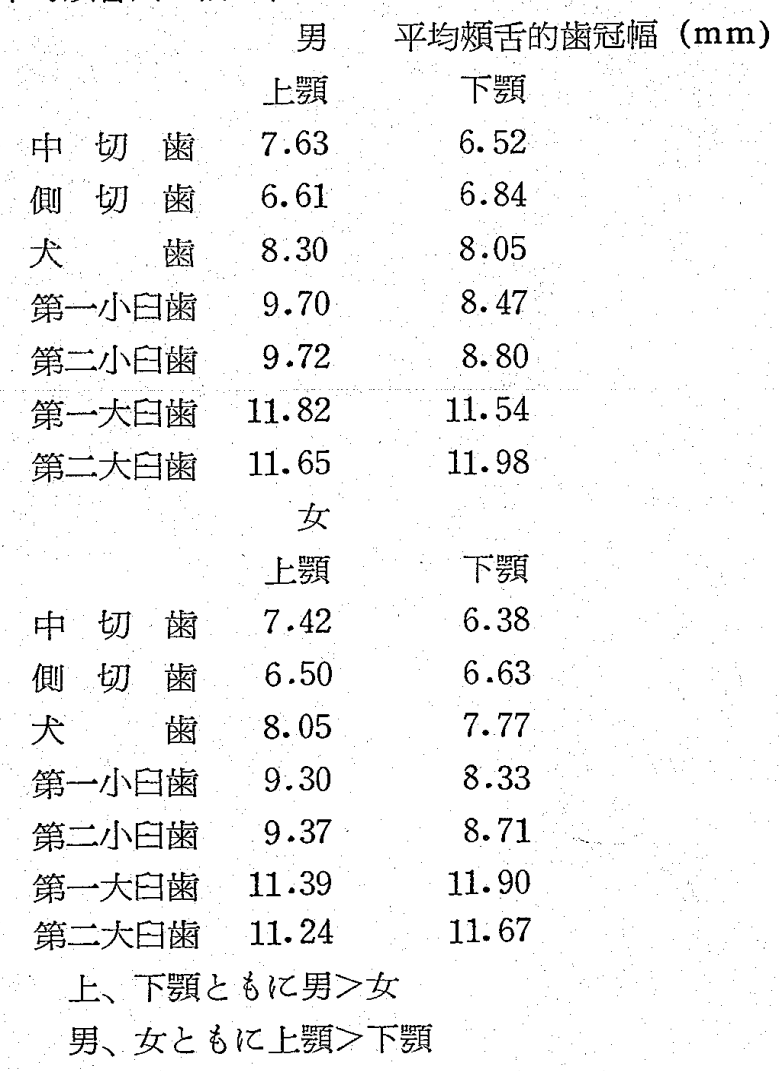

\section{2. 同胞間における煩舌的歯冠幅の相関}

兄弟、娃妹及び兄禁（弟姉）の各組合せ内の上、下 顎左側中切歯、側切歯、犬歯、第一小四菌、第二小曰 䨑、第一大曰䨓及び第二大曰崡の相関係数はつぎの表 のようである。 


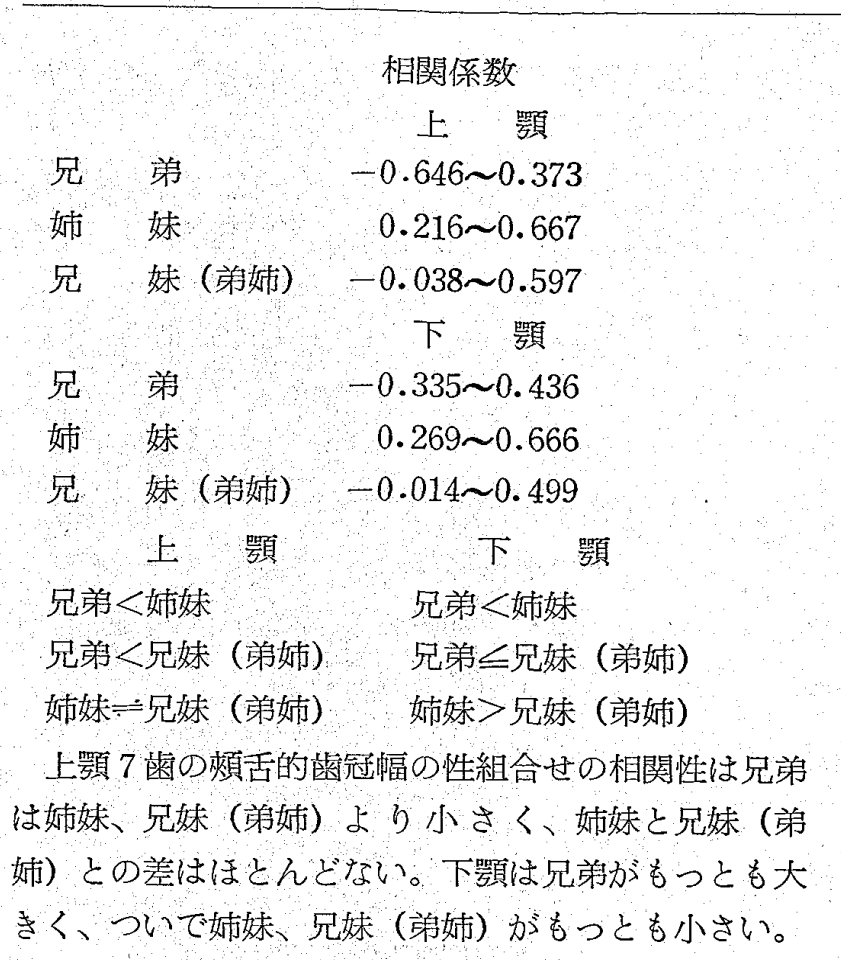

\section{3. 菌列弓周長}

男と女の上、下顎の平均函列弓周長は、つぎの表の ようである。

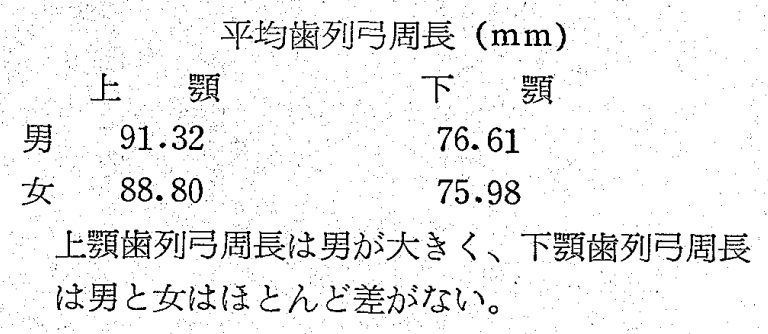

\section{4. 同胞間における菌列弓周長の相関}

兄弟、抒妹及び兄妹（弟姉）の各組 合せ内の、上 顎、下顎各々の相関係数は、つぎのようである。

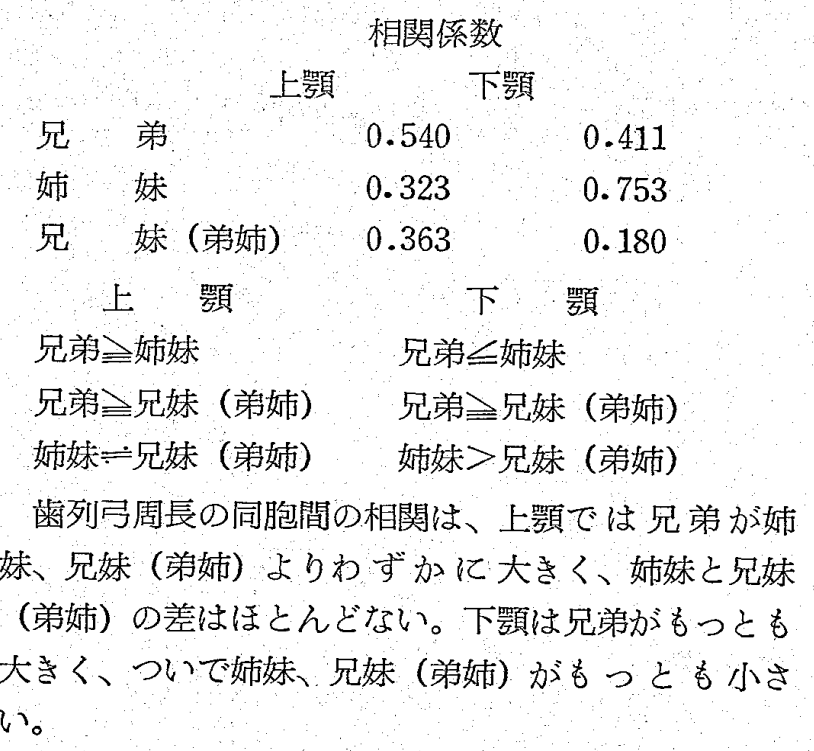

\section{5. 口蓋弓隆長}

男と女の犬歯部、第一小曰霜部、第二小曰霜部及び 第一大白雪部の平均口蓋引隆長と平均口㥺正中縫合線 の長さは、つぎの表のようである。

\section{平均口蓋弓隆長 $(\mathrm{mm})$}

\begin{tabular}{|c|c|c|c|}
\hline 犬菡部口蓋弓隆長 & 27.19 & 26.10 & 男>女 \\
\hline 第一小曰歯部口蓋引隆長 & 34.58 & 32.25 & 男〉女 \\
\hline 第二小曰崡部口瓂亏隆長 & 45.58 & 43.18 & 男>女 \\
\hline 第一大巨䨑部口盖弓隆長 & 50.31 & 48.09 & 男》女 \\
\hline 口琶正中縫合線の長さ。 & 33.58 & 32.65 & 男卫女 \\
\hline
\end{tabular}

\section{6. 同胞間における口蓋弓隆長の相関}

兄弟、姉捇及び兄妹（弟姉）の各組合せの口㥺亏隆 長及び口篮正中縫合線の長さの相関係数は、つぎの表 のようである。

\begin{tabular}{|c|c|c|c|}
\hline & \multicolumn{3}{|c|}{ 相関係数 } \\
\hline & 兄弟 & 㚲妹 & $\begin{array}{l}\text { 兄妹 } \\
\text { (弟姉市) }\end{array}$ \\
\hline 犬歯部口蓋弓隆長 & 0.406 & 0.331 & 0.221 \\
\hline 第一小曰荬部口盖弓隆長 & 0.348 & 0.304 & 0.280 \\
\hline 第二小曰歯部口琴弓隆長 & 0.293 & 0.220 & 0.196 \\
\hline 第一大曰霜部口篮弓隆長 & 0.309 & 0.358 & 0.302 \\
\hline 口蓋正中縫合線の長さ & 0.362 & -0.080 & 0.082 \\
\hline
\end{tabular}

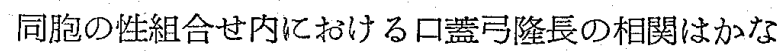
り強く、性組合せ間の相関性はほとんど差がない。

口㥺正中縫合線の長さの相関は、兄弟が姉妹、兄妹 （弟妏）より大きく、姉妹と兄妹（弟姉）との差はほ とんどない。

\section{7. 口蓋幅}

男と女の大齒部、第一小曰歯部、第二小曰歯部及び 第一大四崡部の平均口㥺幅は、つぎの表のようであ る。

\begin{tabular}{|c|c|c|c|}
\hline & \multicolumn{3}{|c|}{ 平均口蓋偪 $(\mathrm{mm})$} \\
\hline & 男 & 女 & 男一女 \\
\hline 部 & 27.05 & 26.56 & 男 \\
\hline 第一小曰歯部 & 30.32 & 29.18 & 男>女 \\
\hline 第二小算部 & 36.07 & 34.27 & 男>女 \\
\hline 第一大曰歯部 & 39.28 & 37.37 & 男>女 \\
\hline
\end{tabular}

口蓋幅は男が女より大である。

\section{8. 同胞間における口蓋幅の相関}

兄弟、姉妹及び兄妹（弟姉）の各組合せ間の口蓋幅 の相関係数は、つぎの表のようである。 


\begin{tabular}{|c|c|c|c|}
\hline & \multicolumn{3}{|c|}{ 相関係数 } \\
\hline & 兄第 & 竗放 & 兄妹（弟妨） \\
\hline 犬 㧘 部 & 0.481 & 0.475 & 0.152 \\
\hline 第一小曰崡部 & 0.625 & 0.497 & 0.209 \\
\hline 第二小四歯部 & 0.462 & 0.666 & 0.112 \\
\hline 第一大曰菌部 & 0.657 & 0.512 & 0.187 \\
\hline
\end{tabular}

口蓋幅の同胞間に扣ける相関は、兄弟と姉妹の差は ほとえどなく、同性組合せ (兄弟、姉妹) が翼性組合 せ（兄妺[弟姉了）より大である。

\section{9. 男と女の口蓋幅と口蓋弓隆長との相関}

男女の大雪部、第一小曰苳部、第二小曰菡部及び第 一大曰部の各々の口䕊幅と口䔔马隆長の相関係数は、 つぎの表のようである。

\begin{tabular}{|c|c|c|c|}
\hline & \multicolumn{3}{|c|}{ 相関係数 } \\
\hline & 男 & 女 & 男一女 \\
\hline 歯 & 0.650 & 0.737 & 男严女 \\
\hline 第一小曰菌部 & 0.667 & 0.732 & 男 女 \\
\hline 第二小曰䨘部 & 0.571 & 0.591 & 男 \\
\hline 第一大曰歯暗 & 0.491 & 0.571 & 男立女 \\
\hline
\end{tabular}

口蓋幅と口蓋引隆長との相関はかなり密接で、男女 間の差はほとんどない。

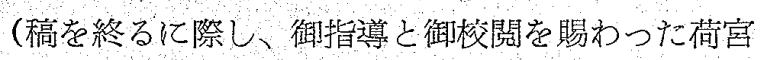
文夫教授感謝の意を表します。)

\section{引用文献}

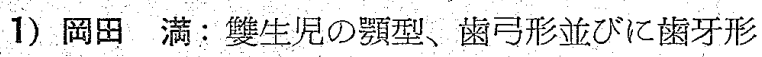
態の類似度の比䡆研究 $(1 \sim 6)$ 、秋科学報、33巻、 $6 、 7 、 9 、 10 、 11$ 号、晤 $3 、 6 、 7 、 9 、 10 、 11 、 34$ 巻、1 号、昭 4,1

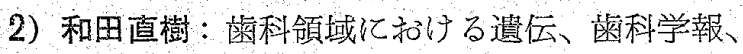
43 巻、 $3 、 5$ 号、昭 $13 、 3 、 5$

3）岩垣 宏: 函列の遗伝に関する研究、曾科学報、 18巻、8号、䁒 13,8

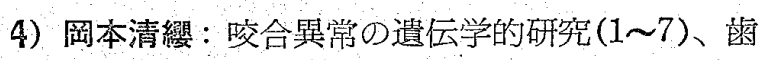
科学報、 44 巻、3 8 号、昭 $14 、 3 \sim 8$

5) 田所幹涁：歯牙及び咬合の遺伝学的研究、双生 巟法江よる研究 $(1 \sim 6)$ 、崡科学報別刷、昭 $29 、 12$ $\sim 30,6$

9）荷宮文夫：日腔の遺伝的研究、I - 血族結婚に よる祝島島民の歯科衛生学的研究、九州崡科学会 雑誌、7巻、1、2号、昭 $28 \cdot 12$

7) 荷宮文夫：日腔の遺伝研究、II双生児に打ける
口腔諸形質の遺伝、九州歯科学会雑誌、9巻、1号、 昭30、6

8）荷宮文夫 : 口腔の遺伝研究、IIの 2 敬点数其の 他の相関、九州䨑科学会猚誌、10巻、1号、昭31、 9

9）荷宮文夫：口腔の頲伝研究，II 親子間に和ける 口腔諸形質の遺伝、九州歯科学会雑誌、10巻、3、 4 号、昭 $32 、 3$

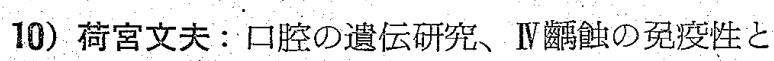
羅患性の研究、崡界展望、15巻、4号、昭33、4

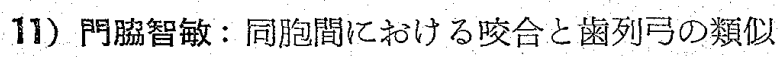
性の研究、医学研究、28巻、6号

12）宮島：亨：歯牙棇転度の研究（崡牙別、近親者 間の相関、䨑列弓との相関)、医学研究、19巻、7 号、昭 $34 、 7 、 31$

13）阿南五郎：奴生览、同胞及び親子に扣ける歯冠 幅の相似性、九州歯科学会雑誌、13巻、1号、昭 34,5

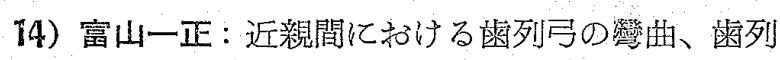
弓及び口蓋の形驡の類似性、13巻、 2 号、昭 34 、 7、 25

15）門本好明：口砀度と昖合、歯列弓、口琣及び口 唇との関係、医学研究、29巻7号、昭34、7、31

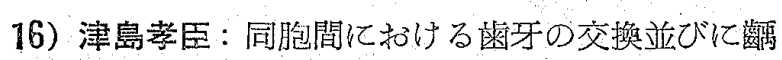
霜の相関、医学研究、30巻、2号、昭 $35 、 2$

17）藤田恒太郎：亚の計剆值について、人類学染 誌、61巻、1昂、昭 $24 、 9$

18）荷宮文夫：受刑精神薄弱者の頭部、顔面及び口 腔形質の研究、九州䨑科学会雑誌、8巻、4号、昭 $30 、 3$

19）㐘地：瀜：東九州の隔離された島（姫島）山村 (木浦木) 住民の頡、顔、口の形態研究、医学研 究、29巻、7昂、擝34、7、31

20）荷宮文走：㕬合と歯马の民族科学的研究、歯科 学雑誌、5巻、4号、昭 $23 、 9$

21）川口球磨男：霜列马並びに口蓋発育の統計学的 研究、医学研究、30巻、4号、炤 $35 、 4$

22）作間博正：同胞、親子間に款ける荬冠傾斜度の 相関、医学研究、30巻、7号、昭 $35 、 7$ 


\title{
A CORRELATION STUDY OF THE BUCCO-LINGUAL CROWN BREADTH AND THE MAGNITUDE OF PAL- ATE IN THE PAIRS OF BROTHERS AND SISTERS
}

\section{A Correlation Study of the Oral Traits}

\author{
By \\ Yukio Ohzawa \\ Department of Hygienics (Director: Prof. Fumio Ninomiya) \\ Kyushu Dental College, Kokura, Japan.
}

It is only in reccents years that hereditary study has been reported by several investigators. Many reports have come from Ninomiya and the associates in his laboratory including Kadowaki, Miyazima, Kadomoto, Sakuma et al. dealing chiefly with a varieties of oral traits such as the dental arch, palate and various tooth-forms as examined among twins, brothers and sisters, parents and children, and other population groups in general.

To date, however, there seems to be no information available as to hereditary study on the bucco-lingual crown breadth, palatal arch length, circumferential length of dental arch and on th breadth of palate.

The present author undertook to make observation on these items of oral traits with special regard to the correlations to be found between pairs of different sex and age combination in brothers and sisters, and the results obtained of some interest were reported here.

A total of 274 subjects of both sexes from 16 to 30 years of age was chosen for the present study, and they were divided into 38 pairs of brothers, 40 pairs of sisters and 59 pairs of brothers and sisters of alternative seniority. Measurement of the morphological details of the mouth was conducted on these 137 pairs of subjects utilizing plaster models of mouth impression taken from every individuals.

Items of Measurement and Method

1) Bucco- lingual crown breadth: all teeth in left upper and lower quadrants except wisdom teeth were measured.

2) Circumferential length of dental arch: outer circumferential length of dental arch from the mesio-buccal cusp of lst molar of one side to that of opposite side

Breadth of palate: respective breadth was measured on the regions of cuspids, 2nd of lst molars. Distance between both lateral incisors was also measured on the singival margin of palatal side.

3) Length of Palatal Arch: individual lengths at the cuspids, 1st bicuspids and 1st molars were measured. Both end points of the distances to be measured were marked on the palatal arch of the plaster models and the fuse wire of appropriate size was pressed along the line connecting these marks of end points, and then extending the wire the full length 
of palatal arch was respectively measured.

4) Length of Median Suture Line of Palate: the distance was measured from the inner dental papilla between both central incisors to the point at which the median suture line crossed with the palatal arch line drawn between both upper 1st molars.

From the values obtained for each item of measurement mean values and variances were respectively calculated for both sexes groups, and difference between the two groups was judged using $t$-test with regard to respective item and mean ratio with regard to the groups in general.

For the purpose of obtaining correlation coefficients between 3 pairs of different combinations, that is, male : male, female: female, male : female, among brothers and sisters studied, standard deviations were computed with respective items studied. Comparison of the correlation coefficients between the groups of different sexes combinations was judged from the difference of two correlation coefficients with regard to each item and from the standard deviation of the difference. Mean ratio was used in the comparison of the groups in general.

The results obtained were summarized as follows.

1) Bucco- Lingual Crown Breadth Average Bucco-Lingual Crown Breadth

$(\mathrm{mm})$

\begin{tabular}{|c|r|r|r|r}
\hline teeth & \multicolumn{2}{|c|}{ male } & \multicolumn{2}{c}{ female } \\
\cline { 2 - 4 } & upper & 1ower & upper & lower \\
central incisor & 7.63 & 6.52 & 7.42 & 6.38 \\
latearal incisor & 6.61 & 6.84 & 6.50 & 6.63 \\
cuspid & 8.30 & 8.05 & 8.06 & 7.77 \\
1st bicuspid & 9.70 & 8.47 & 9.30 & 8.33 \\
2nd bicuspid & 9.72 & 8.80 & 9.37 & 8.71 \\
1st molar & 11.82 & 11.54 & 11.39 & 11.90 \\
2nd molar & 11.65 & 11.98 & 11.24 & 11.67 \\
\hline
\end{tabular}

In either jaw the average value of the crown breadth was greater in the male than in the female and in either sex the one in upper jaw was greater than the one in lower jaw.

2) Correlation Coefficients of the Bucco-Lingual Crown Breadth between Brothers and Sisters

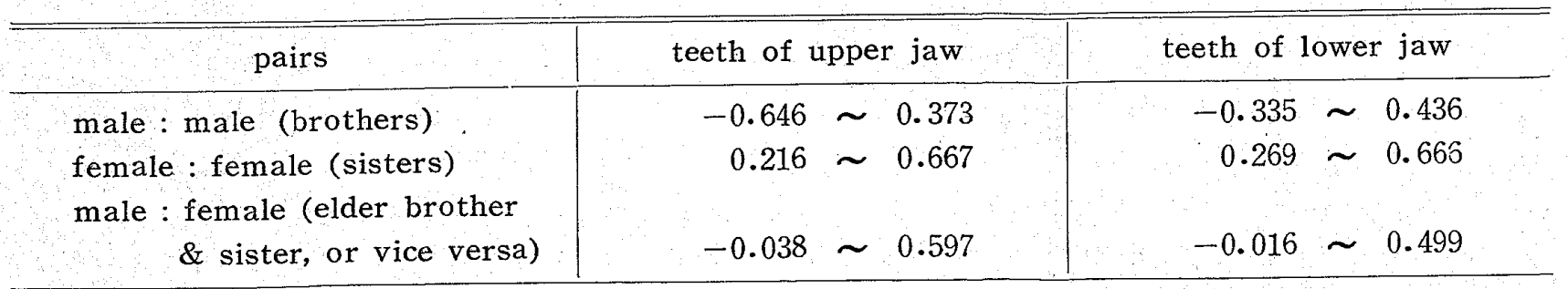

Comparison of the correlation coefficients between every pairs with upper and lower dentitions was given as follows. 


\begin{tabular}{l|l}
\hline upper dentiton & lower dentition \\
brothers $<$ sisters & brothers $<$ sisters \\
brothers $<$ elder brother \& sister (or vice versa) & brothers $\leqslant$ elder brother \& sister (or vice versa) \\
sisters - elder brother \& sister (or vice versa) & sisters $>$ elder brother \& sister (or vice versa)
\end{tabular}

3) Circumferential Length of Dental Arch Average Circumferential Length of Dental $\operatorname{Arch}(\mathrm{mm})$

\begin{tabular}{c|c|c}
\hline \multicolumn{1}{|c|}{} & upper dental arch & lower dental arch \\
male & 91.32 & 76.61 \\
female & 88.80 & 75.98 \\
\hline
\end{tabular}

Evidently the male exceeded the female in the circumferenfial length of dental arch of upper jaw, though in the one of lower jaw the female value was approximately the same with the male value.

4) Correlation Coefficients of Circumferential

Length of Dental Arch Among Brothers and Sisters Combinations

\begin{tabular}{|c|c|c}
\hline \multirow{2}{*}{ combinations } & \multicolumn{2}{|c}{ correlation coefficients } \\
\cline { 2 - 3 } & upper jaw & lower jaw \\
male - male (brothers) & 0.540 & 0.411 \\
male - female (elder brother & 0.323 & 0.753 \\
\& sister or vice versa) & & 0.180 \\
\hline
\end{tabular}

Comparison between pairs of different combinations was given below.

\begin{tabular}{|c|c|}
\hline upper jaw & lower jaw \\
\hline $\begin{array}{l}\text { brothers } \geqq \text { sisters } \\
\text { brothers } \geqq \text { elder brother \& sister (or vice versa) } \\
\text { sisters-elder brother \& sister (or vice versa) }\end{array}$ & $\begin{array}{l}\text { brothers } \leqslant \text { sisters } \\
\text { brothers } \geqq \text { elder brother \& sister (or vice versa) } \\
\text { sisters }>\text { elder brother \& sister (or vice versa) }\end{array}$ \\
\hline
\end{tabular}

5) Length of Palatal Arch Average Length of Palatal Arch (mm)

\begin{tabular}{l|c|c|c}
\hline regions & male & female & comparison \\
\hline cuspid & 27.19 & 26.10 & male $>$ female \\
1st bicuspid & 34.58 & 32.25 & male $>$ female \\
2nd bicuspid & 45.58 & 43.18 & male $>$ female \\
1st molar & 50.31 & 48.09 & male $\lesssim$ female \\
length of median suture line & 33.58 & 32.65 & male $\equiv$ female \\
\hline
\end{tabular}

length of median suture line

$\mathrm{K}=5$ male $>$ female

6) Correlation Coefficients of Palatal Arch Length Among Brothers and Sisters 


\section{Correlation Coefficients}

\begin{tabular}{|l|c|c|c}
\hline \multicolumn{1}{|c|}{ region } & male : female & female : female & male : female \\
\hline cuspid & 0.406 & 0.331 & 0.221 \\
1st bicuspid & 0.348 & 0.304 & 0.280 \\
2nd bicuspid & 0.293 & 0.220 & 0.196 \\
1st molar & 0.309 & 0.358 & 0.302 \\
length of median suture line & 0.362 & -0.080 & 0.082 \\
\hline
\end{tabular}

Comparison of the correlation coefficients between various combinations with palatal arch length

brothers $=$ sisters

brothers -elder brother \& sister (or vice versa)

sisters $=$ elder brother \& sister (or vice versa)

Comparison of the correlation coefficients with length of median sutre line brothers $\triangleq$ sisters brothers $\geqslant$ elder brother \& sister (or vice versa) sisters $=$ elder brother \& sister (or vice versa)

7) Breadth of Palate Average Breadth of palate ( $\mathrm{mm}$ )

\begin{tabular}{|c|c|c|c}
\hline \multicolumn{1}{c|}{ region } & male & female & male-female \\
\hline cuspid & 27.05 & 26.56 & male $\supseteq$ female \\
1st bicuspid & 30.32 & 29.18 & male $>$ female \\
2nd bicuspid & 36.07 & 34.27 & male $>$ female \\
1st molar & 39.28 & 37.37 & male female \\
\hline
\end{tabular}

8) Correlation Coefficients of Palatal Breadth Among Brothers and Sisters

\begin{tabular}{|c|c|c|c|}
\hline \multicolumn{1}{c|}{ region } & male : female & female : female & male : female \\
\hline cuspide & 0.481 & 0.475 & 0.152 \\
1st bicuspid & 0.625 & 0.497 & 0.209 \\
2nd bicuspid & 0.425 & 0.666 & 0.112 \\
1st molar & 0.657 & 0.512 & 0.187 \\
\hline
\end{tabular}

Comparison of the correlation coefficients between various combinations brothers $\div$ sisters brothers $>$ elder brother \& sister (or vice versa) sisters $>$ elder brother \& sister (or vice versa)

9) Correlation Coefficients between Palatal Breadth and Palatal Arch Length in Both Sexes

correlation coefficients

\begin{tabular}{|c|c|c|c}
\hline \multicolumn{1}{c|}{ region } & male & female & male-female \\
\hline cuspid & 0.650 & 0.737 & male $\rightleftharpoons$ female \\
1st bicuspid & 0.667 & 0.732 & male ffemale \\
2nd bicuspid & 0.571 & 0.591 & male female \\
1st molar & 0.491 & 0.571 & male ffemale \\
\hline
\end{tabular}

